Article

\title{
European Banking Integration and Sustainable Economic Growth
}

\author{
Ovidiu Stoica ${ }^{1}$, Otilia-Roxana Oprea ${ }^{1}$, Ionel Bostan ${ }^{2, *} \mathbb{B}$, Carmen Sandu Toderașcu ${ }^{1}(\mathbb{D}$ and \\ Cristina Mihaela Lazăr ${ }^{3}$ \\ 1 Faculty of Economics and Business Administration, Alexandru Ioan Cuza University, 22 Carol I, 700505 Iasi, \\ Romania; ostoica@uaic.ro (O.S.); otiliaoprea40@gmail.com (O.-R.O.); carmentoderascu@gmail.com (C.S.T.) \\ 2 Faculty of Law and Administrative Sciences, Ştefan cel Mare University, Universitatii 13, \\ 720229 Suceava, Romania \\ 3 Faculty of Economic Sciences, Ovidius University, 58 Ion Vodă, 900527 Constanta, Romania; \\ lazarcristinam@yahoo.com \\ * Correspondence: ionel_bostan@yahoo.com or ionel.bostan@fdsa.usv.ro; Tel.: +40-230-216-147
}

Received: 16 December 2019; Accepted: 4 February 2020; Published: 6 February 2020

check for updates

\begin{abstract}
Sustainable economic growth is considered a fundamental problem due to the effects that can be felt on the society as a whole, along with the phenomenon of banking integration that can influence the development of a country's economy. This research aims to investigate the impact of banking market integration on sustainable economic growth in EU countries, especially in the context of financial integration, a good consolidation of the banking market is needed. We also identified the main factors by which the development of the banking market influences economic growth. The analysis was carried out for the period 2004-2018 in EU countries as a sample. According to the results obtained, we can say that European banking integration has a positive influence and has many benefits on the growth and sustainable development of the economy. The main factors by which banking integration significantly and positively favors economic growth are convergence of asset returns, convergence of interest rates, cross-border lending to the non-banking sector, foreign assets and foreign liabilities), the ratio of international banking activities, the ratio between assets and GDP, and the net interest margin (only when maintaining a low level) with some differences between the pre-crisis and the post-crisis period, the countries in the Euro Zone outside the euro, and the new EU member states and the old EU member states.
\end{abstract}

Keywords: growth; sustainability; banking integration; convergence

\section{Introduction}

The existence of an integrated economic system and economic governance capable of responding quickly and efficiently to negative signals from within the European Union, but also from outside, would facilitate the return of the EU to sustainable and smart economic growth, which should generate places for work (a community system) with a major role directed towards solving and monitoring the financial system.

It is necessary to centralize or at least coordinate at a European level the decision to close or rescue international banks, as the closing of an international bank could have cross-border effects and because some small countries in Europe may not be able to finance the rescue of very large banks. European cooperation will be imposed by the failure of the bank, which is caused by the cross-border effects of contagion [1]. Also, the significant factors for the influence of the directive on the inflows of banking assets in a country are the Herfindahl index, which quantifies the tradition of law and order in a country, together with the concentration of the banking system, respectively the dispersion of property [2]. 
Without the extensive adaptation of the banking system, economic and financial integration cannot take place. In the banking sector, the integration is related to the free flow of financial services and the factors of production, mainly capital, cross-border.

Given that financial institutions and functional markets can reduce asymmetric information issues and transaction costs, an important condition for economic growth can be financial development. Also, financial institutions play an increasingly important role in identifying investment opportunities, selecting the most profitable projects, mobilizing economies, facilitating trading, and diversifying risks, as well as improving corporate governance mechanisms. A more efficient credit sector can be a more efficient and important condition for the monetary policy transmission mechanism.

The financial integration process is, on the one hand, a prerequisite for the adoption of the single currency and the implementation of the single monetary policy, with the predominance of banking intermediation in the EU context. On the other hand, this process involves the possibility of causing liquidity crises, which could become contagious and could affect the increasingly integrated financial system.

Another important aspect is the correlation of banking integration with the sustainability of economic growth. Thus, we can say that, through developed and integrated banking products and services, materialized through the quality of relationships between banks and customers, the banking sector can contribute to the sustainable development and growth of each country, through the strategic significance of banks in certain sectors of the economy such as trade, agriculture, energy, and others.

Studies on European banking integration should not only provide scientific explanations for the phenomenon but also guide the banking system towards better integration.

The purpose of the research is to investigate the impact of banking market integration on sustainable economic growth in EU countries, especially in the context of financial integration, as a good consolidation of the banking market is needed. We also set out to identify the main factors by which the development of the banking market influences economic growth. Thus, we used as variables the convergence indicators, the net interest margin, the ratio of international banking activities, foreign assets, foreign liabilities, etc., and fixed effects panel models (across the entire sample and sub-samples).

The originality of this study is the use of a significant number of variables that measure banking integration, which has been proposed by other authors to quantify banking integration but has not been used in growth models. Also, we built a composite index, which measures the impact of bank integration on economic growth. We estimated the influence of the indicators used in different periods and on groups of countries (euro, non-euro, new member states, old member states, pre-crisis period, crisis, and post-crisis period). We used a more recent period for the analysis of our data (2004-2018), most of the studies undertaken previously with data up to 2014. The study contributes to the literature on the impact of bank integration on growth economy, being important for the banking authorities to promote appropriate policies that allow the maintenance and development of certain segments of the banking activity, such as, for example, cross-border financial flows, which stimulate the integration process with a view to the sustainable development and growth of the economy.

\section{Literature Review}

A contribution to the integration process of the banking industry in Europe was the introduction of the euro and the enlargement of the European Union in May 2004.

Countries need to adapt rapidly to increased competition and new market conditions to stimulate economic growth [3]. Particularized in the case of Romania, another study [4] emphasized the importance of EU integration for the banking system, highlighting the main benefits for the Romanian banking system, such as the high competition, which favors the increase of the number of banking services at low prices, and increased efficiency of banking services, which results in a more efficient allocation of resources and better risk management. Moreover, other authors [5] stated that, in the context of European integration, banks with private capital in Romania proved to be more efficient in the period 2004-2008 and benefited from a higher growth productivity as opposed to state banks, which 
highlights the role of expanding banks internationally through mergers and acquisitions. According to Gropp [6], in Germany, banking integration is also important along with both savings and cooperative banks. Another study [7], which was made for Belgium, said that, in the future, most banks operating in Belgium will be smaller in number, larger in size, and operating on a pan-European scale. In France, the cross-border financial linkages are significant, and also the international activity of French banking groups is a factor of the diversification of risks [8]. In Spain, increased international competition is compatible with niches of market power in sub-national markets, and the banking union is designed to complete a monetary union [9].

From other points of view, monetary integration can lead and can be determined by the banking integration process. An analysis of national interest rates indicated the increased integration of the deposits and loans market [10]. Also, another study [11] found that the major role of banks in Western European countries in the banking industries of new EU member states, in terms of their significant holdings, is based on increasing the level of euroization and the process of joining the EMU (Economic and Monetary Union), which stimulates market integration between EU countries.

Significant reimbursements can be generated by the cross-border integration of the banking sector and trade, but these positive results also imply a significant level of risk, as the coefficient of variation for ROE (Return on Equities) increases dramatically [12]. From another point of view, the level of cross-border integration in the retail banking sector has remained very low (evidenced by the low level of lending and cross-border deposit activities), despite the attempt to progress to a single banking market, increasing market competitiveness and reducing barriers to competition have led to a reduction in market power disparity between euro-area banks [13].

The use and access to banking services and the size and concentration of the banking system have opposite effects in terms of the inflows and outflows of banking assets. For example, the higher the level of concentration on the national banking market, or the size of the country, or the degree of banking, the lower the penetration of bank assets from abroad, and also these factors are positively associated with the value of bank assets [14].

From other points of view, the correlation between the rise of house prices is closely linked to this measure of financial integration, namely banking integration. Thus, the increase in the correlation of house prices can be explained by up to a quarter of the banking integration [15]. If the countries have less flexible mortgage markets, characterized by fixed rates of mortgages, low rates of LTV (the ratio between loan and value), it is found that the joint movement of real estate markets can be partially or fully compensated [16].

Other authors [17] concluded that financial intermediaries have a large positive impact on the overall growth of factor productivity, which contributes to the growth of world GDP. Financial intermediaries affect growth by changing economies [18,19].

Given the economic benefits associated with financial integration, the European banking union plays an essential role [20].

Greenfield foreign banks tend to be less efficient, the differences between new domestic private banks and public banks are not significant in terms of cost efficiency, and also this efficiency shows that the negative evolution after EU integration could be due to other causes, such as developing a non-banking financial sector, increasing competition, or adopting regulations that limit bank revenues, in terms of profit efficiency [21]. Better use of existing inputs in financial intermediation is the appropriate approach to improve banking efficiency. Banks must offer a complex menu of the highest quality banking products and services to attract long-standing and reputable manufacturers and companies [22].

The increase in cross-border banking flows, capital flows, and gross external capital positions are factors that have witnessed the intensified global financial integration during the period leading to the Great Financial Crisis. Global financial integration seems to have undermined the scope of independent monetary policy for small and open economies, even though these countries have adopted a flexible exchange regime [23]. Also, banking integration could reduce the potential of people to leave the states in times of crisis, by increasing the ease with which financial capital can reach those states [24]. 
According to the relationship between banking integration and sustainable economic growth, banks that have an integrated and sustainable business strategy system may have the opportunity to develop products and services whose mission is to meet the requirements of social, economic, and environmental issues and also meet the needs of all stakeholders. Also, with the objective of finding viable business cycle solutions, identifying appropriate anti-cyclical public policies and establishing regulations in this regard, it is necessary to understand the role of the main drivers of the sustainable economic growth of a country, among which, capital formation occupies an essential place, as it leads to the increase of the welfare of the society [25]. In fact, sustainable banking brings several business benefits. Research by Global Alliance for Banking on Values (a network of sustainable banks) has shown that sustainable banks have higher and more stable profits, as well as stronger growth than other banks. For these reasons, studying the connection between baking integration and economic growth is very important.

In the literature there have been studies regarding banking integration, but the connection of this phenomenon with the growth of the economy has not been studied, nor have the indicators used by us to measure this connection been used.

To analyze the influence of the characteristics of the banking integration on sustainable economic growth, we have built two key hypotheses:

H1. Banking integration has a positive impact on sustainable economic growth.

H2. Disintegration harms sustainable economic growth during the crisis.

After this review of the literature on this topic, Section 3 discusses the details about the data and methods used in this study, Section 4 presents the empirical results and their analysis, and Section 5 discusses the research implications and concludes the study.

\section{Data and Methodology}

\subsection{Description of Variables}

Studies conducted so far have used various indicators to measure banking integration, from indicators of the structure of the banking system, banking concentration (deposits, loans, Herfindahl index, number of subsidiaries, number of branches, size indicators of the bank (market share of banks) foreign, equity/GDP, market share of each bank in total assets, bank assets/GDP), accessibility indicators of credits (internal credit/GDP), to composite indicators (Lerner index, Theil index-market power in the sector bank, degree of bank openness, degree of bank connection, degree of banking integration, price of capital, price of funds, price of labor), and indicators of bank profitability (ROA, ROE). Another study [6] proposed an indicator of cross-border mergers, insofar as they can be a good proxy for bank integration retail, but we could not use this indicator because we have used annual data, and there is no data for all EU countries and all years regarding mergers and acquisitions. Also, another author [26] proposed a series of indicators for measuring bank integration: the share of foreign branches in the total number of credit institutions, the share of credits granted by the branches of foreign credit institutions in the total volume of loans, and the share of cross-border loans in the non-banking sector. According to the literature, we decided to use in this article the following indicators for measuring banking integration: the ratio of international banking activities, return on assets (ROA) convergence, interest rate convergence, net interest margin, assets/GDP, cross-border flows (external assets and external liabilities), and the share of cross-border loans to non-financial corporations in the total volume of loans.

The ratio of international banking activities (BIAR) (\%) is an indicator proposed by another author [27] for quantifying banking integration. The degree of international financial connection of the banking system of a country with other states is higher if this ratio is higher because the industrialized countries have a higher degree of international financial integration than the less-developed economies. The result of this internationalization is the structure of the world economy, with its specific markets for goods and services, land, capital, labor, monetary, financial, and credit systems [28]. 
Another measure of bank integration is the law of one price. As a proxy for this, an indicator proposed by Gropp [6] is the convergence of return on assets (CONROA) based on the following rationale: "The global banking market is integrated if there is a return on common assets to which all banks converge."

Also, the convergence of interest rates, measured by sigma convergence, is another indicator for measuring bank integration, based on the following idea: the higher the convergence rate, the more integrated banking markets [26,29]. To this end, we used harmonized long-term interest rates for the purpose to assess convergence (CONINT). According to a study by Vacher and Saab [29], they calculated the sigma convergence by the standard deviation of the interest rates, in our case the deviation from the EU average.

The net interest margin (NIM) is an indicator proposed by Vacher and Saab [29] for measuring banking integration, which is well explained by illustrating how a retail bank earns interest from customer deposits. A positive net interest margin indicates that an entity has invested its funds efficiently, which favors bank integration, while a negative return implies that the bank or investment firm has not invested effectively, as interest expenses outweigh the value. Income is generated by investments, and also, the net interest margin is considered a determining factor of economic growth, and the competition between the financial institutions causes a decrease in the net interest margin, which favors economic growth [30].

Assets/GDP (ASS) is another indicator proposed by the literature, which is important for banking integration, because according to another study [31] that referred to the size of the bank, the larger the banking system of the country, the more integration of the international banking sector will be more relevant. Also, other authors [32] stated that a country whose internal financial assets are proportional to its share of the global financial market will have a higher level of financial integration.

Another group of indicators used by the two studies mentioned above is illustrated by the cross-border financial flows, i.e., external assets and external liabilities, (FA and FL) based on the idea that an economy that balances its total cross-border transactions of assets in proportion to its size to the rest of the world will have a higher level of integration, and also a country that strengthens its financial ties with other countries through balanced indirect relations that cross the intermediary countries will have a level higher financial integration. The share of cross-border loans granted to the non-banking sector (CBLNFC) in the total volume of loans is an indicator proposed by Vodova [26] for measuring banking market integration, based on the fact that higher values suggest that foreigners may have easier access to the credit market, which may be an indication of the growing integration of credit markets. Regarding sustainable economic growth, the most common way of measure the growth of the economy in the revised studies is the gross domestic product (GDP). It is used to take into account the relative size of a country, and is also based on the hypothesis that countries with a higher GDP will have a relatively larger domestic internal market, and that the percentage of foreign banks' assets in the country will be lower than in the case of small states. Another less used indicator in the revised studies, but equally important, is labor productivity, because the increases of this indicator (the ratio between the value of production and that of the labor force) have historically been the most important source of real economic growth per capita. We used the total factor productivity indicator (TFP). Sustainability is related to economic growth, because the development of the economy is based on economic growth. Also, the economic dimension of the concept of sustainability says that the development must be economically efficient, in order to be able to distribute financial resources properly among the members of the European Union. The economic growth concept is included in economic development and it is based, especially, on gross domestic product. On the other hand, the sustainable development model is a multidisciplinary concept and it relies on reducing resource consumption, producing clean alternative energy, protection of environment factors, and quality of life in its complexity [33].

Also, according to specialized literature [34], we have used as a control variable of several determinants of economic growth: public spending, inflation, employment (unemployment rate), budget deficit or surplus, and gross national economies. The data are focused on the period 2004-2018 
to compare both the period before the crisis with the one after, euro and non-euro countries, and old EU members and new EU members with an annual frequency obtained from several databases. These samples were from Eurostat, Federal Economic Reserves, Data market, ECB, OECD, World Bank, and the sites of central banks. We considered the 28 countries of the European Union.

Because the data are not routinely distributed, according to the Shapiro-Wilk test, ShewknessKurtosis test and an unbalanced test, we decided to eliminate the extreme values by the process of data winsorization at the $1 \%$ level (keeping the data between the 1 and 99 percentile). Descriptive statistics are presented in the table below (Table 1):

Table 1. Descriptive statistics.

\begin{tabular}{cccccc}
\hline Variables & Obs. & Average & Std.dev. & Min & Max \\
\hline GDP & 392 & 9.89 & 0.68 & 8.16 & 11.39 \\
\hline CBLNFC & 388 & 0.82 & 2.59 & 0.018 & 6.61 \\
\hline UNEM & 392 & 8.94 & 4.22 & 3.70 & 24.90 \\
\hline ASS & 392 & 4.78 & 1.07 & 1.31 & 7.13 \\
\hline CONROA & 392 & 0.46 & 0.59 & 0.004 & 5.93 \\
\hline NIM & 392 & 2.23 & 1.20 & 0.54 & 6.46 \\
\hline FA & 392 & 24.81 & 2.26 & 18.69 & 29.70 \\
\hline TFP & 392 & 1.08 & 0.50 & 0.20 & 4.85 \\
\hline FL & 390 & 12.28 & 2.71 & 7.09 & 20.02 \\
\hline CPI & 392 & 2.15 & 2.11 & -1.68 & 10.92 \\
\hline BDEF & 392 & -2.67 & 3.35 & -13.80 & 5.00 \\
\hline CONINT & 392 & 0.91 & 1.06 & 0.004 & 12.37 \\
\hline PSP & 392 & 44.60 & 7.17 & 17.07 & 58.10 \\
\hline GRS & 391 & 21.75 & 5.70 & 7.98 & 36.73 \\
\hline BIAR & 392 & 11.44 & 3.59 & 2.48 & 22.30 \\
\hline
\end{tabular}

\subsection{Methodology}

In terms of methodology, the models used in the revised research studies to analyze the relationship between banking market integration and economic growth were regressions, VAR, Garch, calculated indicators, ADF, stochastic boundary models, decomposition, Granger causality test, and others.

The research that used the regressions [35] highlighted the functional relationships between the relevant economic, financial, institutional, and technical indicators, according to the specifications of the existing reference literature in this field (banking integration, the role of institutional factors for financial development of the banking system), suggesting that, on the one hand, a higher concentration implies a lower competition, causing the interest of foreign investors to increase. While on the other hand, a higher concentration could represent a lower interest of the banks with regard to when expanding abroad, the expenses with banking activities are proportional to the size of the states, while the inflows of assets register higher levels in the countries with lower banking activity, as opposed to those with a more intense banking activity.

Aziakpono et al. [10] used VAR methodology to investigate the state, development, and drivers of banking market integration in the member countries of the South African Development Community (SADC). Another piece of research used the Garch model to highlight the progress of integration in the European banking industry and its effects on the price of banks' common stock listed on the European stock exchanges, and also whether the introduction of the euro and the enlargement of the European Union in May 2004 contributed to the process of integration of the banking industry in Europe. Some studies used indicators calculated as the Lerner index, Theil index, degree of bank 
openness, degree of bank connection, and degree of bank integration to show the importance of bank integration. For example, Cruz-Garcia et al. [13] used Lerner and Theil indices to analyze the evolution and disparities of market power in the European banking sector. Stavarek [22] used the size-adjusted average efficiency and the size-adjusted scale inefficiency to compare the efficiency of commercial banks, assuming that differences between regions and countries in their stages of European integration and economic development are also visible in banking efficiency. Gallizo et al. [21] used models with stochastic frontiers to analyze how European integration, and in particular property changes, have affected bank efficiency in Central and Eastern European countries.

In this article, we used the multiple regression analysis with fixed effects for the country and time because it is the most suitable for our panel data, according to the statistical tests. The dependent variable is the economic growth, expressed by the GDP and the total factor productivity, and the independent variables are represented by the index of banking integration, built on the variables ROA convergence, the convergence of interest rates, cross-border loans to the non-financial sector, foreign assets, foreign liabilities, variables specific to banking integration, namely, the net interest margin, the ratio between assets and GDP, and the ratio of international banking activities and some control variables (unemployment rate, gross savings, budget deficit or surplus, inflation, public spending).

The multiple regression equation for the fixed effects model has the following form:

$$
\begin{gathered}
\ln _{G D P_{i t}}=\beta_{0}+\beta_{1} \mathrm{BII}+\beta_{2} \mathrm{CPI}+\beta_{3} \mathrm{ASS}+\beta_{4} \mathrm{BIAR}+\beta_{5} \mathrm{NIM}+\beta_{6} \mathrm{PSP}+\beta_{7} \mathrm{GRS}+ \\
\beta_{8} \mathrm{BDEF}+\beta_{9} \mathrm{UNEM}+\alpha_{i}+\varepsilon_{i t}
\end{gathered}
$$

Where the natural logarithm of the gross domestic product is BII-the index of bank integration calculated on the basis of the factor analysis (external assets, foreign liabilities, cross-border loans to the non-financial sector, convergence of interest rates, and ROA convergence), BIAR-the report of international banking activities, NIM — margin of net interest, ASS—assets/GDP, PSP — public spending, CPI—inflation, UNEM — unemployment rate, BDEF—budget deficit or surplus, GRS - gross national economies, $\mathrm{i}$-country, $\mathrm{t}$-time, $(\mathrm{i}=1 \ldots \mathrm{n})$ is the unknown intercept for each country (country-specific intercepts) and the error term. The equation has the same form when we replace GDP with total factor productivity (TFP):

$$
\begin{gathered}
\mathrm{TFP}_{i t}=\beta_{0}+\beta_{1} \mathrm{BII}+\beta_{2} \mathrm{CPI}+\beta_{3} \mathrm{ASS}+\beta_{4} \mathrm{BIAR}+\beta_{5} \mathrm{NIM}+\beta_{6} \mathrm{PSP}+\beta_{7} \mathrm{GRS}+ \\
\beta_{8} \mathrm{BDEF}+\beta_{9} \mathrm{UNEM}+\alpha_{i}+\varepsilon_{i t}
\end{gathered}
$$

Acronyms are used in tables related to descriptive statistics and results. We also built a composite index that measures bank integration. The variables included in the index were: external assets, external liabilities, cross-border lending to the non-financial sector, convergence of interest rates, and ROA convergence because according to the literature, cross-border activity, convergence of interest rates, and ROA (which express the law of a single price) are the most important indicators of banking integration. Unlike Aziakpono et al. [10] study, we applied the factorial analysis, thus obtaining the main factor that explains the evolution of the variables used. According to another study [36], the factorial analysis was used to construct several composite indicators and is useful for analyzing the structure of the sub-indicator sets, which we need in our study, to observe the factors which have an important contribution to the integration process. Moreover, the results of the research carried out by other research [37] confirm the idea that factorial analysis has a greater capacity to capture components. This method does not imply an orthogonal relationship between components (as in the case analysis of the main components), offering the advantage of generating independent components. The KMO test value is 0.57 , which is greater than 0.5 , so the sample is adequate $(0<\mathrm{KMO}<1)$. Also, the probability of Bartlett's sphericity test is less than $0.05(0.00<0.05)$, so that we can apply the factorial analysis on this sample. The criterion for extracting the main factor was that the variance (eigenvalue) is greater than 1 and we also used the Varimax rotation for the factor matrix. We chose the first factor because it was the only one whose variance (eigenvalue) is greater than 1 and we standardized the index 
according to Handbook on Constructing Composite Indicators [38]. The results of the factor analysis are presented in Appendix G.

\section{Results}

We have estimated several models with the proposed variables in the methodology section to see if the results are similar. We also applied several tests for panel data models (heteroskedasticity, country and time effects, serial correlation, and unit root tests) to validate our models. To control autocorrelation, heteroscedasticity, and serial correlation we used the Driscoll-Kraay model with the robust covariance matrix. Regarding multicollinearity, which could be a problem in a regression analysis, if present, we calculated the VIF test, whose values were below 3, so we can say that there are no multicollinearity problems for our models. We performed the Hausman test, to select between random and fixed effects models, and the probability was $0.00<0.05$ for all models, so the models with fixed effects are more suitable. Subsequence tests (Wald test and Wooldridge first-difference test for serial correlation in panels) suggest that fixed-effects models at both country and time levels are more appropriate (time-tested effects suggest that fixed effects are needed in the results of the statistical tests that can be found in annexes 3.2-3.7). Also, for the control of the inverse causality problem, we have estimated several models with a one-year delay (the models with fixed effects of time-Year FE (2) is estimated with lags of independent variables). The eight estimated models used the same variables, the difference being that they are estimated on different samples.

Model 1, which has been estimated for the entire database, shows us that while the banking integration index (BII), the ratio between assets and GDP, and international banking activities have a positive and significant effect in almost all estimates, the variables have a significant influence, but that the net interest margin (NIM), the unemployment rate (UR), and inflation (CPI) are negative. ROA convergence is an important measure of banking integration because convergence is only expected if the structure of the banking industry operates efficiently in different markets, based on the idea that if a bank has negative results in a market, a more efficient competitor should intervene to drive ROA to equilibrium values. Also, as a measure of the law of one price, the convergence of interest rates is an important indicator for banking integration, because the faster the rate of convergence of interest rates, the more integrated banking markets. Convergence plays an important role in sustainable economic growth, as it is considered an essential condition for the economy of European countries, because regions where economic growth and wealth are not evenly spread (convergent), they are not sustainable and can be politically challenged [39]. According to Vodova [26], cross-border loans are also essential indicators for bank integration, because when they have high values, foreigners can have easier access to the regional credit market. Also, according to a study conducted by Bilchak [28], these loans are indicators of cross-border activity and integration throughout the world, as economic integration includes a high level of internationalization, with the aim to create a "developed and sustainable" world economy, which includes its credit, money, financial systems, capital, goods, services, and labor. The unemployment rate has a negative and significant influence on both the gross domestic product and the total factor productivity, because it is in an indirect relation with the growth of the economy, is expected to grow when the economy is in poor shape, and jobs are in short supply. Inflation (expressed by the consumer price index) can have a negative influence on GDP growth if thas high values. The net interest margin (NIM) can have a negative influence on the economic growth, because as we mentioned in the section on data and methodology, it is in an inverse relationship with the growing phenomenon, so that an increase in the interest margin negatively influences the growth of the economy, and a decrease in the interest margin stimulates the growth, as an increase in competition in the financial sector leads to a consolidated financial system and an improvement of the financial market. Another study by Petkovski and Kjosevski [40] obtained similar results, supporting the idea that the net interest margin has a negative influence on growth if it increases. The ratio of international banking activities is also important for economic growth, as global banks are the basis of international service purchases and loans (including for financing projects and trade), and the aggregate share 
of loans granted by these banks has seen a significant increase since 2009 [41]. Also, global banks can significantly influence the link between economics and financing needs, thus stimulating the achievement of sustainable development goals [42]. The ratio between assets and GDP is an important indicator of banking integration, which also refers to the development of the financial system and is strongly correlated with GDP growth [43]. So, according to this model, the first hypothesis (banking integration has a positive influence on sustainable economic growth) is confirmed.

Regarding the differences between the period before the crisis, crisis, and post-crisis, we can see that, in model 2, estimated for the period before the crisis (2004-2007), the results are similar to those of model 1. In model 3, which has been estimated for the crisis period (2008-2010), we can see that the banking integration index (BII), the ratio between assets and GDP, and the ratio of international banking activities have an insignificant and negative influence, both on GDP and on total factor productivity. During the global financial crisis, banks faced major problems in asset management, as well as risks associated with capital, liquidity, loans, and profitability. The declining profitability of the banks is due to the deterioration of the liquidity position and the reduction of lending activities. The quality of bank assets deteriorated significantly during the crisis, due to the increase in the number of non-performing loans with high-interest rates, as a result of the extremely high rate of credit expansion during the pre-crisis period. The inflation rate and the unemployment rate have a negative influence, as their values have increased due to the effects of the crisis. Also, according to a report by the European Central Bank, between 2008 and 2012, cross-border exposures between different countries decreased significantly, by about $20 \%$ [44]. The convergence process was also affected by the crisis, with studies suggesting the emergence of the divergence phenomenon during this period [45]. Thus, we can say that the crisis period was characterized by a significant phenomenon of disintegration [46-49]. During the post-crisis period (model 4), the cross-border exposures of banks decreased significantly, reflecting the decrease in net external debt, which started to return to positive values in 2012-2013 [50]. This is why the ratio of international banking activities has had a negative and significant influence during this period. The result shows that the integration process has started to return to normal after the crisis. So, according to these models, the second hypothesis (disintegration harms sustainable economic growth during the crisis) is confirmed.

Through the differences between the countries of the Eurozone and the non-euro countries (model 5 and model 6), we can see that in the Eurozone, the banking integration index, the ratio between assets and GDP, and the ratio of international banking activities have a significant and positive impact, in contrast to non-euro countries, where they have a negative and insignificant impact in almost all estimates. According to a report of the European Central Bank, the degree of convergence has evolved since the introduction of the euro (1999). This was due to the need for the euro countries to pursue sustainable economic convergence, for several reasons, such as the fact that the Economic and Monetary Union has some special characteristics, which means that this convergence is particularly important when compared, for example, with federal states, such as the United States. Also, facilitating convergence in the Eurozone would also help reverse the divergence trend of the Eurozone compared to other advanced economies [51]. In the Eurozone, the main factors of the outflows of banking assets are the freedom of the national authorities for monitoring and/or banking regulation vis-à-vis the government of each state, the size of the banking system, and the tradition of law and order in the state. Following the adoption of the single euro, the European banking sector has grown quite intensely, European banks have expanded their activity to the European borders and the number of non-performing loans has decreased. Similar results were obtained by Badârcea et al. [2]. So, according to this model, the first hypothesis (banking integration has a positive influence on sustainable economic growth) is confirmed, especially for the Eurozone.

Finally, referring to the differences between the new EU members and the old EU members (model 7 and model 8), we can see that the banking integration index and the ratio of international banking activities have a positive and significant influence on the economic growth in the old ones as well as a significant and negative influence in the new EU member states. Also, the net interest 
margin has a negative and significant influence on the economic growth in the new EU member states, as another indicator of bank integration. From the indicators of banking integration, only the convergence indicators had a significant impact on the process of integration of the new EU members (according to Halmai and Vasary [52], who found that "the success of the integration process of the new Member States was reflected in the performance nominal and real convergence"). Through the financial structure, the new EU member states rely more on bank financing than on direct market financing, the structure of banking systems is dominated by commercial banks, with a share of approximately $90 \%$ of total assets in the banking sector, the states being characterized by a significant presence of foreign banks, especially in the form of subsidiaries of foreign banks (according to an ECB study, on average, $72 \%$ of bank assets are held abroad), and banks in the new member states have equity interests in foreign banks. In the new EU member states, the level of financial intermediation is still low and the market structure of the banking sector is generally characterized by a relatively high concentration, which does not help expansion, discourages foreign investors, and also raises competition issues. Also, the banking integration of the new EU member states has been affected by the quality of assets (which is why the volume of assets has a significant and negative impact), due to the differences between the pace of improper restructuring of loans, macroeconomic conditions, and credit rating rules. Similar results were obtained by the ECB report on banking structures in the new EU member states (October 2017) [53]. So, according to this model, the first hypothesis (banking integration has a positive influence on sustainable economic growth) is confirmed, especially for the old EU members.

In the following Tables 2-9, the pooled OLS model represents a multiple regression of the variables, country FE-country fixed effects regression, year FE-time fixed effects regression, and Year FE (2)-time fixed effects regression in which the independent variables were taken 1 year late.

Table 2. The impact of banking integration on economic growth: Model 1-Initial database.

\begin{tabular}{|c|c|c|c|c|c|c|c|c|}
\hline \multirow{2}{*}{$\begin{array}{l}\text { Independent } \\
\text { Variables }\end{array}$} & \multicolumn{4}{|c|}{ Dependent Variable-GDP } & \multicolumn{4}{|c|}{ Dependent Variable-TFP } \\
\hline & $\begin{array}{l}\text { Pooled } \\
\text { OLS }\end{array}$ & $\begin{array}{c}\text { Country } \\
\text { FE }\end{array}$ & Year FE & $\begin{array}{c}\text { Year FE } \\
\text { (2) }\end{array}$ & $\begin{array}{c}\text { Pooled } \\
\text { OLS }\end{array}$ & $\begin{array}{c}\text { Country } \\
\text { FE }\end{array}$ & Year FE & $\begin{array}{c}\text { Year FE } \\
\text { (2) }\end{array}$ \\
\hline BII & $\begin{array}{c}0.20^{* * *} \\
(0.04)\end{array}$ & $\begin{array}{c}0.35^{* * *} \\
(0.12)\end{array}$ & $\begin{array}{l}0.13^{* * *} \\
(0.06)\end{array}$ & $\begin{array}{c}0.02^{*} \\
(0.019)\end{array}$ & $\begin{array}{c}0.01^{*} \\
(0.003)\end{array}$ & $\begin{array}{c}0.33^{* * *} \\
(0.13)\end{array}$ & $\begin{array}{c}0.11^{* * *} \\
(0.01)\end{array}$ & $\begin{array}{l}0.15^{* *} \\
(0.016)\end{array}$ \\
\hline UNEM & $\begin{array}{c}-0.03^{* * *} \\
(0.01)\end{array}$ & $\begin{array}{c}-0.04^{* * *} \\
(0.01)\end{array}$ & $\begin{array}{c}-0.02^{* * *} \\
(0.007)\end{array}$ & $\begin{array}{c}-0.02^{* * *} \\
(0.01)\end{array}$ & $\begin{array}{c}-0.02^{* * *} \\
(0.01)\end{array}$ & $\begin{array}{c}-0.03^{* *} \\
(0.01)\end{array}$ & $\begin{array}{c}-0.02^{* *} \\
(0.01)\end{array}$ & $\begin{array}{c}-0.02^{* *} \\
(0.01)\end{array}$ \\
\hline NIM & $\begin{array}{c}-0.44^{* * *} \\
(0.03)\end{array}$ & $\begin{array}{c}-0.18^{* * *} \\
(0.05)\end{array}$ & $\begin{array}{c}-0.01^{* * *} \\
(0.01)\end{array}$ & $\begin{array}{c}-0.10^{* * *} \\
(0.03)\end{array}$ & $\begin{array}{l}-0.06^{*} \\
(0.004)\end{array}$ & $\begin{array}{c}-0.14^{* *} \\
(0.06)\end{array}$ & $\begin{array}{c}-0.06^{*} \\
(0.05)\end{array}$ & $\begin{array}{l}-0.10^{*} \\
(0.06)\end{array}$ \\
\hline CPI & $\begin{array}{c}-0.03^{*} \\
(0.02)\end{array}$ & $\begin{array}{c}-0.022^{* * *} \\
(0.02)\end{array}$ & $\begin{array}{c}-0.012^{* * *} \\
(0.01)\end{array}$ & $\begin{array}{c}-0.009^{* * *} \\
(0.001)\end{array}$ & $\begin{array}{c}-0.06 \\
(0.001)\end{array}$ & $\begin{array}{l}-0.006 \\
(0.023)\end{array}$ & $\begin{array}{c}-0.015^{*} \\
(0.03)\end{array}$ & $\begin{array}{l}-0.03^{*} \\
(0.03)\end{array}$ \\
\hline BDEF & $\begin{array}{c}-0.02^{*} \\
(0.01)\end{array}$ & $\begin{array}{l}0.03^{*} \\
(0.01)\end{array}$ & $\begin{array}{c}-0.02^{* * *} \\
(0.008)\end{array}$ & $\begin{array}{c}-0.01^{* * *} \\
(0.01)\end{array}$ & $\begin{array}{c}-0.06^{* *} \\
(0.01)\end{array}$ & $\begin{array}{l}-0.008 \\
(0.018)\end{array}$ & $\begin{array}{c}-0.01^{* *} \\
(0.01)\end{array}$ & $\begin{array}{l}-0.05 \\
(0.02)\end{array}$ \\
\hline PSP & $\begin{array}{c}0.007^{* * *} \\
0.006\end{array}$ & $\begin{array}{l}0.01^{* *} \\
(0.01)\end{array}$ & $\begin{array}{l}-0.05^{* *} \\
(0.005)\end{array}$ & $\begin{array}{c}-0.009^{*} \\
(0.007)\end{array}$ & $\begin{array}{c}-0.02^{* * *} \\
(0.006)\end{array}$ & $\begin{array}{l}-0.01 \\
(0.01)\end{array}$ & $\begin{array}{l}-0.01 \\
(0.01)\end{array}$ & $\begin{array}{l}-0.03 \\
(0.01)\end{array}$ \\
\hline GRS & $\begin{array}{c}0.006 \\
(0.008)\end{array}$ & $\begin{array}{l}0.006^{* *} \\
(0.001)\end{array}$ & $\begin{array}{l}0.01^{* * *} \\
(0.004)\end{array}$ & $\begin{array}{l}0.03^{* * *} \\
(0.006)\end{array}$ & $\begin{array}{c}0.04 \\
(0.008)\end{array}$ & $\begin{array}{c}0.01 \\
(0.01)\end{array}$ & $\begin{array}{c}0.01^{*} \\
(0.011)\end{array}$ & $\begin{array}{l}0.03^{* *} \\
(0.01)\end{array}$ \\
\hline ASS & $\begin{array}{c}0.03^{* * *} \\
(0.03)\end{array}$ & $\begin{array}{l}0.17^{* * *} \\
(0.04)\end{array}$ & $\begin{array}{l}0.15^{* * *} \\
(0.02)\end{array}$ & $\begin{array}{l}0.04^{* * *} \\
(0.008)\end{array}$ & $\begin{array}{l}0.01^{* * *} \\
(0.004)\end{array}$ & $\begin{array}{c}0.03 \\
(0.04)\end{array}$ & $\begin{array}{c}0.07^{* * *} \\
(0.04)\end{array}$ & $\begin{array}{l}0.13^{*} \\
(0.07)\end{array}$ \\
\hline BIAR & $\begin{array}{l}1.08^{* * *} \\
(0.004)\end{array}$ & $\begin{array}{l}0.03^{* * *} \\
(0.002)\end{array}$ & $\begin{array}{l}0.01^{* * *} \\
(0.009)\end{array}$ & $\begin{array}{l}0.08^{* * *} \\
(0.03)\end{array}$ & $\begin{array}{c}0.22 \\
(0.18)\end{array}$ & $\begin{array}{l}0.03^{* * *} \\
(0.02)\end{array}$ & $\begin{array}{l}0.02^{* *} \\
(0.02)\end{array}$ & $\begin{array}{l}0.05^{* *} \\
(0.02)\end{array}$ \\
\hline Cons. & $\begin{array}{c}11.65^{* * *} \\
(0.44)\end{array}$ & $\begin{array}{c}11.27^{* * *} \\
(0.76)\end{array}$ & $\begin{array}{c}10.74^{* * *} \\
(0.34)\end{array}$ & $\begin{array}{c}10.75^{* * * *} \\
(0.49)\end{array}$ & $\begin{array}{c}2.31^{* * *} \\
(0.49)\end{array}$ & $\begin{array}{l}2.16^{* * *} \\
(0.79)\end{array}$ & $\begin{array}{c}2.31^{* * *} \\
(0.74)\end{array}$ & $\begin{array}{c}2.07^{* * * *} \\
(0.84)\end{array}$ \\
\hline
\end{tabular}


Table 2. Cont.

\begin{tabular}{|c|c|c|c|c|c|c|c|c|}
\hline \multirow{2}{*}{$\begin{array}{l}\text { Independent } \\
\text { Variables }\end{array}$} & \multicolumn{4}{|c|}{ Dependent Variable-GDP } & \multicolumn{4}{|c|}{ Dependent Variable-TFP } \\
\hline & $\begin{array}{l}\text { Pooled } \\
\text { OLS }\end{array}$ & $\begin{array}{c}\text { Country } \\
\text { FE }\end{array}$ & Year FE & $\begin{array}{l}\text { Year FE } \\
\text { (2) }\end{array}$ & $\begin{array}{l}\text { Pooled } \\
\text { OLS }\end{array}$ & $\begin{array}{c}\text { Country } \\
\text { FE }\end{array}$ & Year FE & $\begin{array}{c}\text { Year FE } \\
\text { (2) }\end{array}$ \\
\hline R-squared & 0.54 & 0.52 & 0.85 & 0.83 & 0.29 & 0.42 & 0.54 & 0.62 \\
\hline F statistic & $42.75^{* * *}$ & $8.93^{* * *}$ & $69.98^{* * *}$ & $34.32^{* * *}$ & $2.12^{* * *}$ & $5.64^{* * *}$ & $6.94^{* * *}$ & $6.65^{* * *}$ \\
\hline Obs. & 392 & 392 & 392 & 365 & 392 & 392 & 392 & 365 \\
\hline
\end{tabular}

Table 3. The impact of banking integration on economic growth: Model 2-Pre-crisis.

\begin{tabular}{|c|c|c|c|c|c|c|c|c|}
\hline \multirow{2}{*}{$\begin{array}{l}\text { Independent } \\
\text { Variables }\end{array}$} & \multicolumn{4}{|c|}{ Dependent Variable-GDP } & \multicolumn{4}{|c|}{ Dependent Variable-TFP } \\
\hline & $\begin{array}{c}\text { Pooled } \\
\text { OLS }\end{array}$ & $\begin{array}{c}\text { Country } \\
\text { FE }\end{array}$ & Year FE & $\begin{array}{l}\text { Year FE } \\
\text { (2) }\end{array}$ & $\begin{array}{l}\text { Pooled } \\
\text { OLS }\end{array}$ & $\begin{array}{c}\text { Country } \\
\text { FE }\end{array}$ & Year FE & $\begin{array}{c}\text { Year FE } \\
\text { (2) }\end{array}$ \\
\hline BII & $\begin{array}{l}0.09^{* * *} \\
(0.03)\end{array}$ & $\begin{array}{l}0.03^{*} \\
(0.03)\end{array}$ & $\begin{array}{l}0.02^{* *} \\
(0.02)\end{array}$ & $\begin{array}{l}0.03^{* * *} \\
(0.01)\end{array}$ & $\begin{array}{c}0.03^{*} \\
(0.008)\end{array}$ & $\begin{array}{l}0.09^{*} \\
(0.01)\end{array}$ & $\begin{array}{l}0.01^{*} \\
(0.01)\end{array}$ & $\begin{array}{l}0.05^{*} \\
(0.01)\end{array}$ \\
\hline UNEM & $\begin{array}{c}-0.05^{* * *} \\
(0.01)\end{array}$ & $\begin{array}{c}-0.05^{* * *} \\
(0.006)\end{array}$ & $\begin{array}{c}-0.03^{* * *} \\
(0.005)\end{array}$ & $\begin{array}{c}-0.03^{* * *} \\
(0.006)\end{array}$ & $\begin{array}{c}-0.002^{* *} \\
(0.002)\end{array}$ & $\begin{array}{c}-0.01^{* * *} \\
(0.002)\end{array}$ & $\begin{array}{c}-0.005^{*} \\
(0.003)\end{array}$ & $\begin{array}{c}0.002 \\
(0.004)\end{array}$ \\
\hline NIM & $\begin{array}{c}-0.17^{* * *} \\
(0.04)\end{array}$ & $\begin{array}{l}-0.01 \\
(0.01)\end{array}$ & $\begin{array}{c}-0.02 \\
(0.001)\end{array}$ & $\begin{array}{c}-0.04^{* * *} \\
(0.007)\end{array}$ & $\begin{array}{l}-0.01^{*} \\
(0.009)\end{array}$ & $\begin{array}{c}0.002 \\
(0.005)\end{array}$ & $\begin{array}{c}0.004 \\
(0.006)\end{array}$ & $\begin{array}{l}0.005^{*} \\
(0.005)\end{array}$ \\
\hline CPI & $\begin{array}{c}-0.05^{* *} \\
(0.02)\end{array}$ & $\begin{array}{c}0.01^{*} \\
(0.009)\end{array}$ & $\begin{array}{l}0.01^{* *} \\
(0.006)\end{array}$ & $\begin{array}{l}-0.01^{* *} \\
(0.007)\end{array}$ & $\begin{array}{c}0.002 \\
(0.004)\end{array}$ & $\begin{array}{l}0.008^{* *} \\
(0.004)\end{array}$ & $\begin{array}{l}0.007^{* *} \\
(0.003)\end{array}$ & $\begin{array}{c}-0.03 \\
(0.004)\end{array}$ \\
\hline BDEF & $\begin{array}{c}-0.03^{* * *} \\
(0.01)\end{array}$ & $\begin{array}{l}0.008^{*} \\
(0.006)\end{array}$ & $\begin{array}{l}-0.01^{* *} \\
(0.005)\end{array}$ & $\begin{array}{c}-0.015^{* * *} \\
(0.005)\end{array}$ & $\begin{array}{c}-0.03 \\
(0.002)\end{array}$ & $\begin{array}{c}-0.0009 \\
(0.002)\end{array}$ & $\begin{array}{c}-0.006^{* *} \\
(0.003)\end{array}$ & $\begin{array}{c}-0.006^{*} \\
(0.003)\end{array}$ \\
\hline PSP & $\begin{array}{c}0.004 \\
(0.004)\end{array}$ & $\begin{array}{c}0.01 \\
(0.001)\end{array}$ & $\begin{array}{c}0.002 \\
(0.001)\end{array}$ & $\begin{array}{l}-0.004 \\
(0.001)\end{array}$ & $\begin{array}{l}0.0007 \\
(0.001)\end{array}$ & $\begin{array}{l}-0.0008 \\
(0.0008)\end{array}$ & $\begin{array}{c}-0.001 \\
(0.0008)\end{array}$ & $\begin{array}{c}-0.0008^{*} \\
(0.0007)\end{array}$ \\
\hline GRS & $\begin{array}{l}0.04^{* * *} \\
(0.008)\end{array}$ & $\begin{array}{c}-0.005^{* * *} \\
(0.004)\end{array}$ & $\begin{array}{c}-0.01 \\
(0.003)\end{array}$ & $\begin{array}{l}0.002^{*} \\
(0.002)\end{array}$ & $\begin{array}{l}0.002^{*} \\
(0.001)\end{array}$ & $\begin{array}{c}0.001 \\
(0.001)\end{array}$ & $\begin{array}{l}0.002^{*} \\
(0.001)\end{array}$ & $\begin{array}{l}0.0007 \\
(0.001)\end{array}$ \\
\hline ASS & $\begin{array}{c}0.38^{* * * *} \\
(0.08)\end{array}$ & $\begin{array}{c}0.02 \\
(0.02)\end{array}$ & $\begin{array}{c}0.03^{* * *} \\
(0.02)\end{array}$ & $\begin{array}{l}0.03^{* * *} \\
(0.007)\end{array}$ & $\begin{array}{l}0.04^{* *} \\
(0.017)\end{array}$ & $\begin{array}{c}0.01 \\
(0.01)\end{array}$ & $\begin{array}{l}0.02 * \\
(0.01)\end{array}$ & $\begin{array}{c}0.02 \\
(0.005)\end{array}$ \\
\hline BIAR & $\begin{array}{l}0.02^{* * *} \\
(0.008)\end{array}$ & $\begin{array}{c}0.01 \\
(0.01)\end{array}$ & $\begin{array}{c}0.09 \\
(0.01)\end{array}$ & $\begin{array}{l}0.03^{* * *} \\
(0.009)\end{array}$ & $\begin{array}{c}0.005^{* * *} \\
(0.001)\end{array}$ & $\begin{array}{c}0.007 \\
(0.007)\end{array}$ & $\begin{array}{c}0.007 \\
(0.007)\end{array}$ & $\begin{array}{c}0.03^{*} \\
(0.006)\end{array}$ \\
\hline Cons & $\begin{array}{c}8.17^{* * * *} \\
(0.65)\end{array}$ & $\begin{array}{c}10.07^{* * * *} \\
(0.26)\end{array}$ & $\begin{array}{c}10.04^{* * *} \\
(0.19)\end{array}$ & $\begin{array}{l}9.84^{* * *} \\
(0.36)\end{array}$ & $\begin{array}{l}0.78^{* * * *} \\
(0.14)\end{array}$ & $\begin{array}{l}1.05^{* * *} \\
(0.11)\end{array}$ & $\begin{array}{c}1.04^{* * *} \\
(0.10)\end{array}$ & $\begin{array}{c}1.21^{* * *} \\
(0.24)\end{array}$ \\
\hline R-squared & 0.87 & 0.75 & 0.87 & 0.92 & 0.37 & 0.39 & 0.50 & 0.67 \\
\hline F statistic & $61.51^{* * *}$ & $17.87^{* * *}$ & $29.7^{* * *}$ & $29.54^{* * *}$ & $3.51^{* * *}$ & $3.65^{* * *}$ & $3.94^{* * *}$ & $1.38^{* * *}$ \\
\hline Obs. & 112 & 112 & 112 & 83 & 112 & 112 & 112 & 83 \\
\hline
\end{tabular}

Table 4. The impact of banking integration on economic growth: Model 3-Crisis.

\begin{tabular}{ccccccccc}
\hline $\begin{array}{c}\text { Independent } \\
\text { Variables }\end{array}$ & \multicolumn{3}{c}{ Dependent Variable-GDP } & \multicolumn{4}{c}{ Dependent Variable-TFP } \\
\hline & $\begin{array}{c}\text { Pooled } \\
\text { OLS }\end{array}$ & $\begin{array}{c}\text { Country } \\
\text { FE }\end{array}$ & Year FE & $\begin{array}{c}\text { Year FE } \\
\mathbf{( 2 )}\end{array}$ & $\begin{array}{c}\text { Pooled } \\
\text { OLS }\end{array}$ & $\begin{array}{c}\text { Country } \\
\text { FE }\end{array}$ & $\begin{array}{c}\text { Year FE } \\
\text { Year FE } \\
(\mathbf{2})\end{array}$ \\
& 0.05 & 0.03 & -0.01 & 0.08 & -0.006 & -0.005 & 0.02 & -0.009 \\
\multirow{2}{*}{ BII } & $(0.04)$ & $(0.04)$ & $(0.05)$ & $(0.01)$ & $(0.006)$ & $(0.01)$ & $(0.02)$ & $(0.03)$ \\
\hline \multirow{2}{*}{ UNEM } & $-0.08^{* * *}$ & -0.002 & $-0.01^{* *}$ & -0.005 & $-0.005^{* *}$ & $-0.005^{* *}$ & $-0.003^{* *}$ & $-0.01^{* *}$ \\
& $(0.01)$ & $(0.005)$ & $(0.005)$ & $(0.001)$ & $(0.002)$ & $(0.002)$ & $(0.002)$ & $(0.005)$ \\
\hline
\end{tabular}


Table 4. Cont.

\begin{tabular}{ccccccccc}
\hline $\begin{array}{c}\text { Independent } \\
\text { Variables }\end{array}$ & \multicolumn{3}{c}{ Dependent Variable-GDP } & \multicolumn{3}{c}{ Dependent Variable-TFP } \\
\hline & $\begin{array}{c}\text { Pooled } \\
\text { OLS }\end{array}$ & $\begin{array}{c}\text { Country } \\
\text { FE }\end{array}$ & Year FE & $\begin{array}{c}\text { Year FE } \\
\mathbf{( 2 )}\end{array}$ & $\begin{array}{c}\text { Pooled } \\
\text { OLS }\end{array}$ & $\begin{array}{c}\text { Country } \\
\text { FE }\end{array}$ & $\begin{array}{c}\text { Year FE } \\
\text { Year FE } \\
(\mathbf{2})\end{array}$ \\
\hline \multirow{2}{*}{ NIM } & $-0.40^{* * *}$ & -0.003 & -0.02 & 0.04 & 0.01 & $0.02^{* *}$ & $0.01^{*}$ & $0.01^{* *}$ \\
& $(0.04)$ & $(0.02)$ & $(0.002)$ & $(0.005)$ & $(0.006)$ & $(0.01)$ & $(0.01)$ & $(0.01)$ \\
\hline \multirow{2}{*}{ CPI } & $-0.03^{*}$ & 0.006 & -0.005 & 0.01 & $0.005^{* *}$ & $-0.009^{* * *}$ & $-0.005^{* *}$ & -0.001 \\
& $(0.01)$ & $(0.004)$ & $(0.004)$ & $(0.008)$ & $(0.002)$ & $(0.001)$ & $(0.002)$ & $(0.002)$ \\
\hline \multirow{2}{*}{ BDEF } & -0.001 & -0.006 & -0.04 & -0.06 & -0.04 & -0.01 & -0.004 & -0.001 \\
& $(0.01)$ & $(0.009)$ & $(0.008)$ & $(0.001)$ & $(0.001)$ & $(0.003)$ & $(0.004)$ & $(0.005)$ \\
\hline \multirow{2}{*}{ PSP } & 0.01 & -0.01 & -0.06 & -0.01 & 0.001 & -0.02 & -0.005 & -0.04 \\
& $(0.008)$ & $(0.009)$ & $(0.008)$ & $(0.01)$ & $(0.001)$ & $(0.003)$ & $(0.004)$ & $(0.006)$ \\
\hline \multirow{2}{*}{ GRS } & -0.0009 & 0.002 & -0.00002 & -0.02 & -0.07 & $-0.002^{* *}$ & 0.007 & -0.004 \\
& $(0.008)$ & $(0.002)$ & $(0.0002)$ & $(0.004)$ & $(0.001)$ & $(0.0009)$ & $(0.001)$ & $(0.001)$ \\
\hline \multirow{2}{*}{ ASS } & 0.06 & 0.02 & -0.02 & 0.02 & 0.02 & -0.008 & -0.007 & 0.02 \\
& $(0.004)$ & $(0.02)$ & $(0.02)$ & $(0.008)$ & $(0.006)$ & $(0.009)$ & $(0.01)$ & $(0.002)$ \\
\hline \multirow{2}{*}{ BIAR } & $-0.01^{* * *}$ & -0.004 & -0.05 & -0.09 & -0.001 & -0.01 & -0.02 & -0.04 \\
& $(0.01)$ & $(0.008)$ & $(0.007)$ & $(0.001)$ & $(0.001)$ & $(0.003)$ & $(0.003)$ & $(0.005)$ \\
\hline \multirow{2}{*}{ Cons } & $11.10^{* * *}$ & $10.37^{* * * *}$ & $10.59^{* * *}$ & $10.64^{* * *}$ & $0.97^{* * *}$ & $1^{* * * *}$ & $1.23^{* * *}$ & $0.95^{* * * *}$ \\
& $(0.49)$ & $(0.51)$ & $(0.46)$ & $(1.12)$ & $(0.07)$ & $(0.19)$ & $(0.22)$ & $(0.36)$ \\
\hline R-squared & 0.88 & 0.43 & 0.69 & 0.58 & 0.31 & 0.78 & 0.81 & 0.55 \\
\hline F statistic & $41.97^{* * *}$ & $2.50^{* * *}$ & $5.50^{* * *}$ & $1.12^{* * *}$ & $2.55^{* * *}$ & $11.85^{* * *}$ & $10.73^{* * *}$ & $1.01^{* * *}$ \\
\hline Obs. & 83 & 83 & 83 & 55 & 83 & 83 & 83 & 55 \\
\hline
\end{tabular}

Table 5. The impact of banking integration on economic growth: Model 4-Post-crisis.

\begin{tabular}{ccccccccc}
\hline $\begin{array}{c}\text { Independent } \\
\text { Variables }\end{array}$ & \multicolumn{3}{c}{ Dependent Variable-GDP } & \multicolumn{3}{c}{ Dependent Variable-TFP } \\
& $\begin{array}{c}\text { Pooled } \\
\text { OLS }\end{array}$ & $\begin{array}{c}\text { Country } \\
\text { FE }\end{array}$ & Year FE & $\begin{array}{c}\text { Year FE } \\
\mathbf{( 2 )}\end{array}$ & $\begin{array}{c}\text { Pooled } \\
\text { OLS }\end{array}$ & $\begin{array}{c}\text { Country } \\
\text { FE }\end{array}$ & $\begin{array}{c}\text { Year FE } \\
\text { Year FE } \\
(2)\end{array}$ \\
\hline \multirow{2}{*}{ BII } & $0.27^{* * *}$ & $0.01^{*}$ & $-0.92^{* * *}$ & $0.51^{*}$ & $-0.05^{*}$ & $1.16^{*}$ & $1.35^{* *}$ & $0.60^{*}$ \\
& $(0.07)$ & $(0.03)$ & $(0.25)$ & $(0.48)$ & $(0.007)$ & $(0.58)$ & $(0.54)$ & $(0.58)$ \\
\hline \multirow{2}{*}{ UNEM } & $-0.005^{* *}$ & $-0.15^{* * *}$ & $-0.02^{* * *}$ & $-0.04^{* * *}$ & $-0.04^{*}$ & $-0.22^{* * *}$ & $-0.19^{* * *}$ & $-0.18^{* * *}$ \\
& $(0.02)$ & $(0.03)$ & $(0.02)$ & $(0.04)$ & $(0.02)$ & $(0.04)$ & $(0.04)$ & $(0.06)$ \\
\hline \multirow{2}{*}{ NIM } & $0.57^{* * *}$ & $-0.18^{*}$ & -0.08 & $0.18^{*}$ & $0.13^{*}$ & -0.18 & 0.19 & 0.15 \\
& $(0.07)$ & $(0.10)$ & $(0.05)$ & $(0.09)$ & $(0.07)$ & $(0.12)$ & $(0.12)$ & $(0.01)$ \\
\hline \multirow{2}{*}{ CPI } & -0.01 & $-0.06^{* * *}$ & -0.004 & -0.01 & 0.07 & $-0.05^{* *}$ & -0.07 & -0.03 \\
& $(0.04)$ & $(0.04)$ & $(0.003)$ & $(0.006)$ & $(0.04)$ & $(0.05)$ & $(0.008)$ & $(0.09)$ \\
\hline \multirow{2}{*}{ BDEF } & $0.06^{* *}$ & $-0.04^{* *}$ & $-0.03^{* * *}$ & $-0.02^{* *}$ & -0.0002 & $-0.06^{* *}$ & $-0.13^{* * *}$ & $-0.12^{* *}$ \\
& $(0.02)$ & $(0.04)$ & $(0.02)$ & $(0.004)$ & $(0.01)$ & $(0.05)$ & $(0.05)$ & $(0.06)$ \\
\hline \multirow{2}{*}{ PSP } & 0.007 & $-0.02^{* * *}$ & $-0.01^{* * *}$ & $-0.02^{* *}$ & $-0.03^{* *}$ & $-0.08^{* *}$ & $-0.11^{* *}$ & $-0.07^{* *}$ \\
& $(0.001)$ & $(0.004)$ & $(0.002)$ & $(0.003)$ & $(0.01)$ & $(0.04)$ & $(0.04)$ & $(0.05)$ \\
\hline
\end{tabular}


Table 5. Cont.

\begin{tabular}{ccccccccc}
\hline $\begin{array}{c}\text { Independent } \\
\text { Variables }\end{array}$ & \multicolumn{3}{c}{ Dependent Variable-GDP } & \multicolumn{3}{c}{ Dependent Variable-TFP } \\
\hline & $\begin{array}{c}\text { Pooled } \\
\text { OLS }\end{array}$ & $\begin{array}{c}\text { Country } \\
\text { FE }\end{array}$ & Year FE & $\begin{array}{c}\text { Year FE } \\
\mathbf{( 2 )}\end{array}$ & $\begin{array}{c}\text { Pooled } \\
\text { OLS }\end{array}$ & $\begin{array}{c}\text { Country } \\
\text { FE }\end{array}$ & $\begin{array}{c}\text { Year FE } \\
\text { Year FE } \\
(2)\end{array}$ \\
\hline \multirow{2}{*}{ GRS } & 0.002 & $0.02^{* * *}$ & $0.02^{* *}$ & $0.02^{* * *}$ & -0.003 & -0.03 & -0.05 & -0.02 \\
& $(0.001)$ & $(0.003)$ & $(0.01)$ & $(0.02)$ & $(0.01)$ & $(0.03)$ & $(0.03)$ & $(0.004)$ \\
\hline \multirow{2}{*}{ ASS } & $0.11^{* *}$ & 0.50 & -0.23 & -0.03 & -0.03 & $-0.01^{*}$ & $-0.13^{* *}$ & $-0.37^{* * *}$ \\
& $(0.05)$ & $(0.07)$ & $(0.04)$ & $(0.01)$ & $(0.006)$ & $(0.009)$ & $(0.09)$ & $(0.19)$ \\
\hline \multirow{2}{*}{ BIAR } & $0.03^{* *}$ & $0.06^{* * *}$ & 0.03 & -0.02 & 0.02 & $0.03^{*}$ & $0.3^{*}$ & $-0.23^{* * *}$ \\
& $(0.02)$ & $(0.04)$ & $(0.02)$ & $(0.005)$ & $(0.02)$ & $(0.005)$ & $(0.05)$ & $(0.08)$ \\
\hline \multirow{2}{*}{ Cons } & $12.07^{* * *}$ & $13.72^{* * *}$ & $11.90^{* * *}$ & $11.95^{* * *}$ & $2.56^{* * *}$ & $8.48^{* * *}$ & $9.88^{* * *}$ & $10.17^{* * *}$ \\
& $(0.73)$ & $(2.36)$ & $(1.21)$ & $(2.13)$ & $(0.75)$ & $(2.82)$ & $(2.64)$ & $(3.28)$ \\
\hline R-squared & 0.45 & 0.78 & 0.86 & 0.70 & 0.45 & 0.51 & 0.44 & 0.48 \\
\hline F statistic & $16.27^{* * * *}$ & $11.37^{* * *}$ & $53.82^{* * *}$ & $19.12^{* * *}$ & $3.46^{* * *}$ & $5.83^{* * *}$ & $6.40^{* *}$ & $5.63^{* * *}$ \\
\hline Obs. & 196 & 196 & 196 & 167 & 196 & 196 & 196 & 167 \\
\hline
\end{tabular}

${ }^{* * *} p<0.01,{ }^{* *} p<0.05,{ }^{*} p<0.1$ Robust standard errors are in parentheses.

Table 6. The impact of banking integration on economic growth: Model 5-Eurozone.

\begin{tabular}{|c|c|c|c|c|c|c|c|c|}
\hline \multirow{2}{*}{$\begin{array}{l}\text { Independent } \\
\text { Variables }\end{array}$} & \multicolumn{4}{|c|}{ Dependent Variable-GDP } & \multicolumn{4}{|c|}{ Dependent Variable-TFP } \\
\hline & $\begin{array}{c}\text { Pooled } \\
\text { OLS }\end{array}$ & $\begin{array}{l}\text { Country } \\
\text { FE }\end{array}$ & Year FE & $\begin{array}{l}\text { Year FE } \\
\text { (2) }\end{array}$ & $\begin{array}{c}\text { Pooled } \\
\text { OLS }\end{array}$ & $\begin{array}{l}\text { Country } \\
\text { FE }\end{array}$ & Year FE & $\begin{array}{c}\text { Year FE } \\
\text { (2) }\end{array}$ \\
\hline BII & $\begin{array}{c}0.55^{* * *} \\
(0.05)\end{array}$ & $\begin{array}{c}0.30^{* * *} \\
(0.12)\end{array}$ & $\begin{array}{l}0.07^{* *} \\
(0.06)\end{array}$ & $\begin{array}{l}0.07^{* * *} \\
(0.01)\end{array}$ & $\begin{array}{l}0.11^{*} \\
(0.07)\end{array}$ & $\begin{array}{l}0.36^{* *} \\
(0.17)\end{array}$ & $\begin{array}{l}0.22^{*} \\
(0.17)\end{array}$ & $\begin{array}{l}0.17^{* *} \\
(0.22)\end{array}$ \\
\hline UNEM & $\begin{array}{c}-0.01^{* * *} \\
(0.01)\end{array}$ & $\begin{array}{c}-0.01^{* * *} \\
(0.01)\end{array}$ & $\begin{array}{c}-0.01^{* * *} \\
(0.008)\end{array}$ & $\begin{array}{c}-0.01^{* * *} \\
(0.001)\end{array}$ & $\begin{array}{l}-0.02^{*} \\
(0.01)\end{array}$ & $\begin{array}{l}-0.01^{*} \\
(0.002)\end{array}$ & $\begin{array}{l}-0.02^{*} \\
(0.02)\end{array}$ & $\begin{array}{c}-0.05^{* *} \\
(0.02)\end{array}$ \\
\hline NIM & $\begin{array}{c}-0.12^{* * *} \\
(0.05)\end{array}$ & $\begin{array}{c}-0.05 \\
(0.007)\end{array}$ & $\begin{array}{l}-0.02 \\
(0.03)\end{array}$ & $\begin{array}{l}-0.01^{* *} \\
(0.005)\end{array}$ & $\begin{array}{l}-0.03 \\
(0.07)\end{array}$ & $\begin{array}{c}-0.06 \\
(0.009)\end{array}$ & $\begin{array}{c}-0.09 \\
(0.009)\end{array}$ & $\begin{array}{l}-0.03 \\
(0.01)\end{array}$ \\
\hline CPI & $\begin{array}{c}-0.05^{* * *} \\
(0.02)\end{array}$ & $\begin{array}{c}-0.05^{* * *} \\
(0.02)\end{array}$ & $\begin{array}{l}-0.01 \\
(0.01)\end{array}$ & $\begin{array}{l}-0.01^{* *} \\
(0.002)\end{array}$ & $\begin{array}{c}-0.02 \\
(0.003)\end{array}$ & $\begin{array}{c}-0.2 \\
(0.03)\end{array}$ & $\begin{array}{l}-0.03 \\
(0.04)\end{array}$ & $\begin{array}{l}-0.01^{* *} \\
(0.005)\end{array}$ \\
\hline BDEF & $\begin{array}{c}0.02 \\
(0.01)\end{array}$ & $\begin{array}{l}0.04^{* * * *} \\
(0.001)\end{array}$ & $\begin{array}{l}-0.07^{* *} \\
(0.008)\end{array}$ & $\begin{array}{l}-0.005 \\
(0.001)\end{array}$ & $\begin{array}{c}-0.006 \\
(0.01)\end{array}$ & $\begin{array}{l}-0.01 \\
(0.02)\end{array}$ & $\begin{array}{c}-0.009^{*} \\
(0.02)\end{array}$ & $\begin{array}{c}-0.05^{\text {** }} \\
(0.02)\end{array}$ \\
\hline PSP & $\begin{array}{l}0.05^{* *} \\
(0.006)\end{array}$ & $\begin{array}{l}0.01^{* * *} \\
(0.01)\end{array}$ & $\begin{array}{c}-0.03 \\
(0.005)\end{array}$ & $\begin{array}{c}-0.07 \\
(0.008)\end{array}$ & $\begin{array}{c}-0.012^{*} \\
(0.007)\end{array}$ & $\begin{array}{l}-0.008 \\
(0.01)\end{array}$ & $\begin{array}{l}-0.01 \\
(0.01)\end{array}$ & $\begin{array}{l}-0.06 \\
(0.01)\end{array}$ \\
\hline GRS & $\begin{array}{c}0.008 \\
(0.008)\end{array}$ & $\begin{array}{c}0.07^{*} \\
(0.009)\end{array}$ & $\begin{array}{c}0.006^{* * *} \\
(0.004)\end{array}$ & $\begin{array}{c}0.007^{* * * *} \\
(0.007)\end{array}$ & $\begin{array}{c}0.01 \\
(0.01)\end{array}$ & $\begin{array}{c}0.02 \\
(0.01)\end{array}$ & $\begin{array}{l}0.02 * \\
(0.01)\end{array}$ & $\begin{array}{l}0.03^{* *} \\
(0.01)\end{array}$ \\
\hline ASS & $\begin{array}{l}0.22^{* * *} \\
(0.004)\end{array}$ & $\begin{array}{l}0.28^{* * *} \\
(0.04)\end{array}$ & $\begin{array}{c}0.27^{* * *} \\
(0.02)\end{array}$ & $\begin{array}{l}0.01^{* * *} \\
(0.006)\end{array}$ & $\begin{array}{c}0.06 \\
(0.05)\end{array}$ & $\begin{array}{l}0.08^{* *} \\
(0.06)\end{array}$ & $\begin{array}{c}0.05^{*} \\
(0.006)\end{array}$ & $\begin{array}{l}0.28^{* *} \\
(0.12)\end{array}$ \\
\hline BIAR & $\begin{array}{c}0.02^{* * *} \\
(0.01)\end{array}$ & $\begin{array}{l}0.01^{* * * *} \\
(0.002)\end{array}$ & $\begin{array}{c}0.07^{* * *} \\
(0.01)\end{array}$ & $\begin{array}{l}0.02^{* *} \\
(0.02)\end{array}$ & $\begin{array}{c}0.02 \\
(0.01)\end{array}$ & $\begin{array}{l}0.08^{* * * *} \\
(0.03)\end{array}$ & $\begin{array}{l}0.06^{* *} \\
(0.02)\end{array}$ & $\begin{array}{l}0.07^{* *} \\
(0.03)\end{array}$ \\
\hline Cons & $\begin{array}{c}12.10^{* * * *} \\
(0.49)\end{array}$ & $\begin{array}{c}11.62^{* * *} \\
(0.69)\end{array}$ & $\begin{array}{c}11.27^{* * *} \\
(0.35)\end{array}$ & $\begin{array}{c}10.47^{* * * *} \\
(0.59)\end{array}$ & $\begin{array}{c}1.57^{* * *} \\
(0.61)\end{array}$ & $\begin{array}{l}1.92^{* * *} \\
(0.95)\end{array}$ & $\begin{array}{c}2.56^{* * *} \\
(0.95)\end{array}$ & $\begin{array}{c}2.45^{* * *} \\
(1.11)\end{array}$ \\
\hline R-squared & 0.57 & 0.63 & 0.85 & 0.70 & 0.40 & 0.45 & 0.58 & 0.55 \\
\hline F statistic & $28.95^{* * *}$ & $7.48^{* * *}$ & $39.24^{* * *}$ & $10.03^{* * *}$ & $2.21^{* * *}$ & $3.32^{* * *}$ & $3.48^{* * *}$ & $3.77^{* * *}$ \\
\hline Obs. & 252 & 252 & 252 & 231 & 252 & 252 & 252 & 231 \\
\hline
\end{tabular}


Table 7. The impact of banking integration on economic growth: Model 6-Non-euro.

\begin{tabular}{|c|c|c|c|c|c|c|c|c|}
\hline \multirow{2}{*}{$\begin{array}{l}\text { Independent } \\
\text { Variables }\end{array}$} & \multicolumn{4}{|c|}{ Dependent Variable-GDP } & \multicolumn{4}{|c|}{ Dependent Variable-TFP } \\
\hline & $\begin{array}{c}\text { Pooled } \\
\text { OLS }\end{array}$ & $\begin{array}{c}\text { Country } \\
\text { FE }\end{array}$ & Year FE & $\begin{array}{c}\text { Year FE } \\
\text { (2) }\end{array}$ & $\begin{array}{c}\text { Pooled } \\
\text { OLS }\end{array}$ & $\begin{array}{c}\text { Country } \\
\text { FE }\end{array}$ & Year FE & $\begin{array}{c}\text { Year FE } \\
\text { (2) }\end{array}$ \\
\hline BII & $\begin{array}{l}-0.11^{*} \\
(0.10)\end{array}$ & $\begin{array}{c}-0.76^{* *} \\
(0.22)\end{array}$ & $\begin{array}{c}-0.10^{* * *} \\
(0.01)\end{array}$ & $\begin{array}{c}-0.21^{*} \\
(0.12)\end{array}$ & $\begin{array}{l}0.17^{*} \\
(0.09)\end{array}$ & $\begin{array}{l}0.42 \\
0.18\end{array}$ & $\begin{array}{l}-0.11 \\
(0.02)\end{array}$ & $\begin{array}{c}0.12 \\
(0.03)\end{array}$ \\
\hline UNEM & $\begin{array}{c}-0.05^{* * *} \\
(0.02)\end{array}$ & $\begin{array}{c}-0.07^{* * *} \\
(0.02)\end{array}$ & $\begin{array}{c}-0.03^{* * *} \\
(0.01)\end{array}$ & $\begin{array}{c}-0.03^{* * *} \\
(0.01)\end{array}$ & $\begin{array}{c}-0.02^{*} \\
(0.02)\end{array}$ & $\begin{array}{c}-0.05^{* * *} \\
(0.02)\end{array}$ & $\begin{array}{c}-0.05^{* * *} \\
(0.02)\end{array}$ & $\begin{array}{c}-0.05^{* * *} \\
(0.03)\end{array}$ \\
\hline NIM & $\begin{array}{c}-0.47^{* * *} \\
(0.07)\end{array}$ & $\begin{array}{c}-0.20^{* *} \\
(0.10)\end{array}$ & $\begin{array}{c}-0.03^{* * *} \\
(0.004)\end{array}$ & $\begin{array}{c}-0.04^{* * *} \\
(0.04)\end{array}$ & $\begin{array}{c}-0.02^{*} \\
(0.06)\end{array}$ & $\begin{array}{c}-0.26^{* *} \\
(0.09)\end{array}$ & $\begin{array}{l}-0.10^{*} \\
(0.010)\end{array}$ & $\begin{array}{c}-0.09^{*} \\
(0.02)\end{array}$ \\
\hline CPI & $\begin{array}{l}-0.01 \\
(0.03)\end{array}$ & $\begin{array}{l}-0.04 \\
(0.03)\end{array}$ & $\begin{array}{c}-0.01^{* * *} \\
(0.01)\end{array}$ & $\begin{array}{c}-0.01^{*} \\
(0.01)\end{array}$ & $\begin{array}{c}-0.001 \\
(0.02)\end{array}$ & $\begin{array}{c}-0.05^{*} \\
(0.02)\end{array}$ & $\begin{array}{l}-0.01^{*} \\
(0.004)\end{array}$ & $\begin{array}{l}-0.05^{*} \\
(0.04)\end{array}$ \\
\hline BDEF & $\begin{array}{l}0.03^{* *} \\
(0.02)\end{array}$ & $\begin{array}{c}-0.02^{* * *} \\
(0.03)\end{array}$ & $\begin{array}{c}-0.02^{* * * *} \\
(0.01)\end{array}$ & $\begin{array}{c}-0.03^{*} \\
(0.01)\end{array}$ & $\begin{array}{c}-0.008^{*} \\
(0.02)\end{array}$ & $\begin{array}{l}-0.04 \\
(0.03)\end{array}$ & $\begin{array}{c}-0.05^{* *} \\
(0.03)\end{array}$ & $\begin{array}{c}-0.05^{*} \\
(0.04)\end{array}$ \\
\hline PSP & $\begin{array}{c}0.01^{* * * *} \\
(0.02)\end{array}$ & $\begin{array}{l}-0.06^{*} \\
(0.04)\end{array}$ & $\begin{array}{c}-0.02^{* * *} \\
(0.01)\end{array}$ & $\begin{array}{c}-0.02^{* * *} \\
(0.01)\end{array}$ & $\begin{array}{c}-0.03^{* *} \\
(0.01)\end{array}$ & $\begin{array}{c}-0.06^{*} \\
(0.03)\end{array}$ & $\begin{array}{c}-0.04^{*} \\
(0.03)\end{array}$ & $\begin{array}{l}-0.07^{*} \\
(0.04)\end{array}$ \\
\hline GRS & $\begin{array}{l}-0.01 \\
(0.01)\end{array}$ & $\begin{array}{c}0.05^{* * *} \\
(0.02)\end{array}$ & $\begin{array}{c}0.01 \\
(0.01)\end{array}$ & $\begin{array}{c}0.001 \\
(0.001)\end{array}$ & $\begin{array}{c}0.008 \\
(0.001)\end{array}$ & $\begin{array}{c}0.03 \\
(0.02)\end{array}$ & $\begin{array}{l}-0.02 \\
(0.02)\end{array}$ & $\begin{array}{l}-0.07 \\
(0.03)\end{array}$ \\
\hline ASS & $\begin{array}{l}0.08^{* * * *} \\
(0.07)\end{array}$ & $\begin{array}{c}0.06 \\
(0.009)\end{array}$ & $\begin{array}{c}-0.06^{* *} \\
(0.03)\end{array}$ & $\begin{array}{c}0.05 \\
(0.04)\end{array}$ & $\begin{array}{l}-0.07 \\
(0.06)\end{array}$ & $\begin{array}{c}-0.18^{*} \\
(0.07)\end{array}$ & $\begin{array}{c}-0.29^{* * *} \\
(0.07)\end{array}$ & $\begin{array}{l}-0.03 \\
(0.01)\end{array}$ \\
\hline BIAR & $\begin{array}{c}0.03^{* * * *} \\
(0.03)\end{array}$ & $\begin{array}{l}0.13^{* *} \\
(0.07)\end{array}$ & $\begin{array}{c}-0.07^{* * * *} \\
(0.02)\end{array}$ & $\begin{array}{l}0.07^{* *} \\
(0.03)\end{array}$ & $\begin{array}{l}-0.03 \\
(0.02)\end{array}$ & $\begin{array}{c}0.02^{* *} \\
(0.006)\end{array}$ & $\begin{array}{c}-0.04^{* *} \\
(0.005)\end{array}$ & $\begin{array}{l}-0.04 \\
(0.08)\end{array}$ \\
\hline Cons & $\begin{array}{c}10.25^{* * *} \\
(1.15)\end{array}$ & $\begin{array}{c}14.41^{* * *} \\
(2.27)\end{array}$ & $\begin{array}{c}11.52^{* * *} \\
(0.78)\end{array}$ & $\begin{array}{c}12.06^{* * *} \\
(0.95)\end{array}$ & $\begin{array}{c}3.55^{* * *} \\
(1.01)\end{array}$ & $\begin{array}{l}4.59^{* * *} \\
(1.92)\end{array}$ & $\begin{array}{c}3.84^{* * *} \\
(1.85)\end{array}$ & $\begin{array}{l}2.96^{* * *} \\
(2.37)\end{array}$ \\
\hline R-squared & 0.67 & 0.67 & 0.93 & 0.94 & 0.45 & 0.48 & 0.51 & 0.53 \\
\hline F statistic & $27.49^{* * *}$ & $6.71^{* * *}$ & $68.38^{* * *}$ & $71.65^{* * *}$ & $2.30^{* * *}$ & $6.43^{* * *}$ & $4.95^{* * *}$ & $3.08^{* * *}$ \\
\hline Obs. & 140 & 140 & 140 & 128 & 140 & 140 & 140 & 128 \\
\hline
\end{tabular}

Table 8. The impact of banking integration on economic growth: Model 7-Old EU members.

\begin{tabular}{ccccccccc}
\hline $\begin{array}{c}\text { Independent } \\
\text { Variables }\end{array}$ & \multicolumn{3}{c}{ Dependent Variable-GDP } & \multicolumn{3}{c}{ Dependent Variable-TFP } \\
\hline & $\begin{array}{c}\text { Pooled } \\
\text { OLS }\end{array}$ & $\begin{array}{c}\text { Country } \\
\text { FE }\end{array}$ & Year FE & $\begin{array}{c}\text { Year FE } \\
\mathbf{( 2 )}\end{array}$ & $\begin{array}{c}\text { Pooled } \\
\text { OLS }\end{array}$ & $\begin{array}{c}\text { Country } \\
\text { FE }\end{array}$ & $\begin{array}{c}\text { Year FE } \\
\text { Year FE } \\
(2)\end{array}$ \\
\hline \multirow{2}{*}{ BII } & $0.28^{* * *}$ & $0.71^{* * *}$ & $0.14^{* *}$ & $0.13^{* *}$ & $0.03^{*}$ & $0.08^{*}$ & $0.11^{*}$ & $0.04^{* *}$ \\
& $(0.07)$ & $(0.18)$ & $(0.08)$ & $(0.013)$ & $(0.02)$ & $(0.07)$ & $(0.10)$ & $(0.01)$ \\
\hline \multirow{2}{*}{ UNEM } & $-0.04^{* * *}$ & $-0.04^{* * *}$ & $-0.02^{* *}$ & $-0.02^{*}$ & $-0.01^{*}$ & $-0.01^{*}$ & $-0.02^{*}$ & $-0.02^{*}$ \\
& $(0.02)$ & $(0.02)$ & $(0.01)$ & $(0.01)$ & $(0.008)$ & $(0.01)$ & $(0.01)$ & $(0.01)$ \\
\hline \multirow{2}{*}{ NIM } & $-0.12^{* * *}$ & $0.26^{* *}$ & $-0.03^{*}$ & $-0.15^{* *}$ & 0.08 & -0.06 & $-0.08^{* *}$ & -0.02 \\
& $(0.08)$ & $(0.11)$ & $(0.004)$ & $(0.07)$ & $(0.03)$ & $(0.04)$ & $(0.05)$ & $(0.005)$ \\
\hline \multirow{2}{*}{ CPI } & $-0.04^{* * *}$ & $-0.01^{* *}$ & $-0.03^{* *}$ & $-0.01^{*}$ & -0.01 & $-0.03^{*}$ & $-0.06^{* *}$ & $-0.01^{*}$ \\
& $(0.004)$ & $(0.004)$ & $(0.02)$ & $(0.004)$ & $(0.01)$ & $(0.02)$ & $(0.03)$ & $(0.003)$ \\
\hline \multirow{2}{*}{ BDEF } & 0.02 & $-0.04^{* *}$ & $-0.01^{* * *}$ & $-0.01^{* *}$ & $-0.02^{* * *}$ & $-0.04^{* * *}$ & $-0.04^{* *}$ & $-0.04^{* *}$ \\
& $(0.01)$ & $(0.03)$ & $(0.01)$ & $(0.002)$ & $(0.007)$ & $(0.01)$ & $(0.01)$ & $(0.01)$ \\
\hline \multirow{2}{*}{ PSP } & $-0.06^{* *}$ & $-0.02^{* * *}$ & $-0.03^{* * *}$ & $-0.04^{* * *}$ & $-0.009^{* *}$ & $-0.03^{* *}$ & $-0.03^{*}$ & $-0.03^{* *}$ \\
& $(0.008)$ & $(0.003)$ & $(0.01)$ & $(0.001)$ & $(0.003)$ & $(0.01)$ & $(0.01)$ & $(0.01)$ \\
\hline
\end{tabular}


Table 8. Cont.

\begin{tabular}{ccccccccc}
\hline $\begin{array}{c}\text { Independent } \\
\text { Variables }\end{array}$ & \multicolumn{3}{c}{ Dependent Variable-GDP } & \multicolumn{3}{c}{ Dependent Variable-TFP } \\
\hline & $\begin{array}{c}\text { Pooled } \\
\text { OLS }\end{array}$ & $\begin{array}{c}\text { Country } \\
\text { FE }\end{array}$ & Year FE & $\begin{array}{c}\text { Year FE } \\
\mathbf{( 2 )}\end{array}$ & $\begin{array}{c}\text { Pooled } \\
\text { OLS }\end{array}$ & $\begin{array}{c}\text { Country } \\
\text { FE }\end{array}$ & $\begin{array}{c}\text { Year FE } \\
\text { Year FE } \\
(2)\end{array}$ \\
\hline \multirow{2}{*}{ GRS } & 0.09 & $0.006^{* * *}$ & $0.01^{* * *}$ & 0.01 & $0.01^{* * *}$ & $0.01^{* * *}$ & $0.01^{* *}$ & $0.01^{* *}$ \\
& $(0.01)$ & $(0.001)$ & $(0.006)$ & $(0.009)$ & $(0.004)$ & $(0.007)$ & $(0.007)$ & $(0.007)$ \\
\hline \multirow{2}{*}{ ASS } & $0.32^{* *}$ & $0.39^{* * *}$ & $0.22^{* *}$ & 0.04 & 0.007 & 0.02 & 0.02 & 0.02 \\
& $(0.07)$ & $(0.07)$ & $(0.03)$ & $(0.008)$ & $(0.002)$ & $(0.003)$ & $(0.04)$ & $(0.006)$ \\
\hline \multirow{2}{*}{ BIAR } & $0.07^{* *}$ & $0.07^{*}$ & $0.02^{* *}$ & $0.02^{* * *}$ & 0.01 & 0.07 & $0.07^{*}$ & $0.01^{* * *}$ \\
& $(0.01)$ & $(0.04)$ & $(0.01)$ & $(0.002)$ & $(0.005)$ & $(0.01)$ & $(0.02)$ & $(0.002)$ \\
\hline \multirow{2}{*}{ Cons } & $13.23^{* * *}$ & $11.52^{* * *}$ & $11.23^{* * *}$ & $11.20^{* * *}$ & $1.33^{* * *}$ & $2.54^{* * *}$ & $2.93^{* * *}$ & $2.07^{* * *}$ \\
& $(0.65)$ & $(1.67)$ & $(0.62)$ & $(1.04)$ & $(0.25)$ & $(0.69)$ & $(0.77)$ & $(0.83)$ \\
\hline R-squared & 0.54 & 0.58 & 0.92 & 0.79 & 0.42 & 0.50 & 0.56 & 0.50 \\
\hline F statistic & $7.44^{* * *}$ & $7.27^{* * *}$ & $76.45^{* * *}$ & $22.53^{* * *}$ & $2.73^{* * *}$ & $3.78^{* * *}$ & $1.84^{* * *}$ & $1.88^{* * *}$ \\
\hline Obs. & 210 & 210 & 163 & 210 & 210 & 210 & 210 & 163 \\
\hline
\end{tabular}

${ }^{* * *} p<0.01,{ }^{* *} p<0.05,{ }^{*} p<0.1$ Robust standard errors are in parentheses.

Table 9. The impact of banking integration on economic growth: Model 8-New EU members.

\begin{tabular}{|c|c|c|c|c|c|c|c|c|}
\hline \multirow[t]{2}{*}{$\begin{array}{l}\text { Independent } \\
\text { Variables }\end{array}$} & \multicolumn{4}{|c|}{ Dependent Variable-GDP } & \multicolumn{4}{|c|}{ Dependent Variable-TFP } \\
\hline & $\begin{array}{c}\text { Pooled } \\
\text { OLS }\end{array}$ & $\begin{array}{c}\text { Country } \\
\text { FE }\end{array}$ & Year FE & $\begin{array}{l}\text { Year FE } \\
\text { (2) }\end{array}$ & $\begin{array}{c}\text { Pooled } \\
\text { OLS }\end{array}$ & $\begin{array}{c}\text { Country } \\
\text { FE }\end{array}$ & Year FE & $\begin{array}{l}\text { Year FE } \\
\text { (2) }\end{array}$ \\
\hline BII & $\begin{array}{l}-0.06 \\
(0.04)\end{array}$ & $\begin{array}{c}-0.36^{* *} \\
(0.13)\end{array}$ & $\begin{array}{c}0.08 \\
(0.009)\end{array}$ & $\begin{array}{c}0.07 \\
(0.01)\end{array}$ & $\begin{array}{c}0.18 \\
(0.09)\end{array}$ & $\begin{array}{c}0.61 \\
(0.27)\end{array}$ & $\begin{array}{c}-0.25^{* * *} \\
(0.22)\end{array}$ & $\begin{array}{l}-0.11 \\
(0.02)\end{array}$ \\
\hline UNEM & $\begin{array}{c}-0.05^{* * *} \\
(0.01)\end{array}$ & $\begin{array}{c}-0.04^{* * *} \\
(0.01)\end{array}$ & $\begin{array}{c}-0.03^{* * *} \\
(0.01)\end{array}$ & $\begin{array}{c}-0.04^{* *} \\
(0.01)\end{array}$ & $\begin{array}{l}-0.02^{*} \\
(0.02)\end{array}$ & $\begin{array}{c}-0.04^{*} \\
(0.02)\end{array}$ & $\begin{array}{l}-0.01^{*} \\
(0.02)\end{array}$ & $\begin{array}{l}-0.02^{*} \\
(0.003)\end{array}$ \\
\hline NIM & $\begin{array}{c}-0.33^{* * *} \\
(0.05)\end{array}$ & $\begin{array}{c}-0.17^{* *} \\
(0.06)\end{array}$ & $\begin{array}{l}-0.08 \\
(0.04)\end{array}$ & $\begin{array}{c}-0.17^{* * *} \\
(0.05)\end{array}$ & $\begin{array}{c}-0.22^{* *} \\
(0.09)\end{array}$ & $\begin{array}{l}-0.22^{*} \\
(0.12)\end{array}$ & $\begin{array}{l}-0.06 \\
(0.01)\end{array}$ & $\begin{array}{c}-0.06^{* *} \\
(0.01)\end{array}$ \\
\hline CPI & $\begin{array}{c}-0.02^{* * *} \\
(0.01)\end{array}$ & $\begin{array}{c}-0.007^{* *} \\
(0.01)\end{array}$ & $\begin{array}{l}-0.01 \\
(0.01)\end{array}$ & $\begin{array}{l}-0.007 \\
(0.02)\end{array}$ & $\begin{array}{c}0.02 \\
(0.03)\end{array}$ & $\begin{array}{c}0.02 \\
(0.03)\end{array}$ & $\begin{array}{c}0.06 \\
(0.04)\end{array}$ & $\begin{array}{c}-0.01 \\
(0.005)\end{array}$ \\
\hline BDEF & $\begin{array}{l}-0.06 \\
(0.01)\end{array}$ & $\begin{array}{c}-0.05^{* *} \\
(0.01)\end{array}$ & $\begin{array}{c}-0.05^{* * *} \\
(0.01)\end{array}$ & $\begin{array}{c}-0.04^{* *} \\
(0.01)\end{array}$ & $\begin{array}{l}-0.04 \\
(0.03)\end{array}$ & $\begin{array}{c}0.04 \\
(0.03)\end{array}$ & $\begin{array}{c}-0.01^{* *} \\
(0.003)\end{array}$ & $\begin{array}{l}-0.06^{*} \\
(0.03)\end{array}$ \\
\hline PSP & $\begin{array}{l}-0.01^{*} \\
(0.008)\end{array}$ & $\begin{array}{c}-0.01^{* * *} \\
(0.009)\end{array}$ & $\begin{array}{c}-0.008^{*} \\
(0.007)\end{array}$ & $\begin{array}{c}-0.02 \\
(0.001)\end{array}$ & $\begin{array}{l}-0.01 \\
(0.01)\end{array}$ & $\begin{array}{l}-0.01 \\
(0.01)\end{array}$ & $\begin{array}{l}-0.01 \\
(0.01)\end{array}$ & $\begin{array}{l}-0.09 \\
(0.01)\end{array}$ \\
\hline GRS & $\begin{array}{c}-0.05 \\
(0.001)\end{array}$ & $\begin{array}{c}0.01^{* * *} \\
(0.01)\end{array}$ & $\begin{array}{c}0.008^{* * *} \\
(0.008)\end{array}$ & $\begin{array}{l}0.03^{* * *} \\
(0.01)\end{array}$ & $\begin{array}{c}-0.01 \\
(0.002)\end{array}$ & $\begin{array}{l}-0.06 \\
(0.02)\end{array}$ & $\begin{array}{c}0.03 \\
(0.02)\end{array}$ & $\begin{array}{l}-0.03 \\
(0.02)\end{array}$ \\
\hline ASS & $\begin{array}{l}0.06^{* *} \\
(0.04)\end{array}$ & $\begin{array}{l}0.04^{* * *} \\
(0.006)\end{array}$ & $\begin{array}{c}-0.04^{* *} \\
(0.03)\end{array}$ & $\begin{array}{c}-0.15^{* *} \\
(0.06)\end{array}$ & $\begin{array}{l}-0.03 \\
(0.08)\end{array}$ & $\begin{array}{c}0.02 \\
(0.01)\end{array}$ & $\begin{array}{c}-0.09 \\
(0.009)\end{array}$ & $\begin{array}{c}-0.20^{* *} \\
(0.13)\end{array}$ \\
\hline BIAR & $\begin{array}{c}0.06 \\
(0.01)\end{array}$ & $\begin{array}{c}-0.04^{* *} \\
(0.02)\end{array}$ & $\begin{array}{c}-0.005^{* * *} \\
(0.01)\end{array}$ & $\begin{array}{l}-0.01^{*} \\
(0.02)\end{array}$ & $\begin{array}{c}-0.2 \\
(0.02)\end{array}$ & $\begin{array}{c}-0.10^{* * *} \\
(0.04)\end{array}$ & $\begin{array}{c}-0.07^{* * *} \\
(0.03)\end{array}$ & $\begin{array}{l}0.07^{* *} \\
(0.04)\end{array}$ \\
\hline Cons & $\begin{array}{c}9.93^{* * *} \\
(0.57)\end{array}$ & $\begin{array}{c}9.80^{* * *} \\
(0.73)\end{array}$ & $\begin{array}{c}9.64^{* * *} \\
(0.50)\end{array}$ & $\begin{array}{c}10.84^{* * *} \\
(0.66)\end{array}$ & $\begin{array}{c}2.67^{* * *} \\
(1.06)\end{array}$ & $\begin{array}{c}3.73^{* * *} \\
(1.50)\end{array}$ & $\begin{array}{l}2.93^{* * *} \\
(1.19)\end{array}$ & $\begin{array}{c}2.08^{* * * *} \\
(1.35)\end{array}$ \\
\hline R-squared & 0.56 & 0.51 & 0.78 & 0.75 & 0.50 & 0.41 & 0.67 & 0.60 \\
\hline F statistic & $13.83^{* * *}$ & $8.15^{* * *}$ & $18.44^{* * *}$ & $15.73^{* * *}$ & $2.63^{* * *}$ & $3.88^{* * *}$ & $8.65^{* * *}$ & $7.58^{* * * *}$ \\
\hline Obs. & 182 & 182 & 182 & 170 & 182 & 182 & 182 & 170 \\
\hline
\end{tabular}




\section{Conclusions}

The positive correlation between the development of the banking market and economic growth is a well-known fact from an empirical point of view.

The purpose of this study was to investigate the relationship between banking integration and sustainable economic growth in the countries of the European Union and to see what are the main factors by which the development of the banking market influences economic growth. This objective was achieved by our research, our results confirm that banking integration has a positive and significant influence on sustainable economic growth, and also the hypothesis proposed at the data and methodology section have been confirmed.

We used the multiple regression for fixed effects panel models (country and time effects) to investigate the effects of bank integration on economic growth. In this model, we introduced a composite index constructed using factorial analysis. The obtained results show that the main factors by which banking integration significantly and positively favors economic growth (confirming the first hypothesis proposed for verification in this study) are convergence of asset returns, convergence of interest rates, cross-border lending to the non-banking sector, foreign assets and foreign liabilities, the ratio of international banking activities, the ratio between assets and GDP, and the net interest margin (only when maintaining a low level) with some differences between the pre-crisis and the post-crisis period, the countries in the Euro Zone outside the euro, the new EU member states, and the old EU member states.

The crisis period had a negative impact on banking integration, (confirming the second research hypothesis in this study), which led to the reduction of cross-border exposures and the negative impact of bank integration indicators on economic growth, as well as the unemployment rate and inflation, with a negative impact on the activities of the banking sector. This period is characterized by the phenomenon of disintegration because the crisis caused the divergence of the economy, the fragmentation of financial flows, the erosion of the political support of the EU institutions, and the establishment of Europeans against each other.

In the Eurozone, the main factors by which banking integration positively and significantly influences economic growth are the convergence indicators, which are more developed than in non-euro countries. Additionally, after the adoption of the single euro, the European banking sector developed quite intensely, European banks have expanded their activity at European borders, and the number of non-performing loans has decreased.

In the new EU member states, from the indicators of banking integration, only the convergence indicators had a significant impact on the integration process, all the other indicators having a negative impact, mainly due to the financial structure of the banks.

According to our results, we can say that the banking market integration contributes significantly to the sustainable economic growth in the EU countries, especially in the old member states, Eurozone, and before the global financial crisis.

The policymakers in this area should pay attention to reducing the volume of non-performing loans, as they have a significant and negative influence on the development of the banking sector and economic growth. They are the main factors of the banking crises, maintaining a stable level of interest rates to stimulate lending activities and economic growth, attracting renowned and long-term companies and producers, the most credible and sought after customers. They also stimulate sustainable economic convergence, as banks must offer a complex menu of the highest quality banking products and services. As this segment is highly competitive, credit institutions should expand their lending activities, especially in the household and small- and medium-sized businesses. Another crucial issue is the large-scale inefficiency of large banks (as measured by the ratio of assets to GDP) because they are too large for their real output, and the path to greater efficiency does not lead to the establishment of new branches and the hiring of new people. Moreover, regulatory authorities should focus their attention on ensuring that the benefits of banking reform processes are sustained and take decisive steps to tighten the risk management framework in the banking sector, as this will have a 
positive effect on the profitability of banks. It is also necessary to encourage cross-border activities between countries, as they can have important channels through which banking integration promotes economic growth. Governments should pay greater attention to internal stability, promoting policies aimed at macroeconomic stability, reducing the interest rate margin and resolving the problem of political instability, because an economy with good internal economic stability would contribute to a contraction of the net interest margin, with growth effect. To stimulate convergence and sustainable economic growth, especially for the countries of the Eurozone, the activities of banking union should be influenced, so that the capital markets become more integrated, the modification of the fiscal norms to encourage investments and the establishment of a Eurozone budget to mitigate cyclical fluctuations. Also, in order to stimulate sustainability, the banking system requires an integrated business strategy, the professionalism of the persons responsible for the banking management, a careful collection and analysis of the data, the organization of budgets according to sustainability criteria, a good cooperation with the international banks, and the incorporation of the sustainable development objectives in the bank management.

We consider that international or cross-border banking integration is in agreement with other authors, the most significant financial integration. To facilitate financial services and free capital flow across national borders, the degree of international banking integration can be seen through different measures, because internationalization is an instrumental means in ensuring a fertile ground for financial innovation and securitization.

Banking integration can be seen as a convergence process in a single market (characterized by a single price) for banking products and services, in which all buyers and sellers within the union have opportunities to trade on the most favorable terms.

The connection between financing and growth is significantly influenced by the regulation and supervision of banks. Inflation affects not only the economic growth but also the financial activities of a country by affecting the interest rates, which have a direct effect on the collection of deposits and the mobilization of the activities of financial and banking institutions.

An efficient banking sector reduces transaction costs and the margin between lending rates and deposits. The share of savings allocated to investments increases, and following the theory of endogenous growth, leads to greater economic growth.

Author Contributions: Conceptualization, O.S., O.-R.O., I.B., C.S.T., and C.M.L.; methodology, O.S., O.-R.O., I.B., C.S.T., and C.M.L.; software, O.S., O.-R.O., I.B., C.S.T., and C.M.L.; validation, O.S., O.-R.O., I.B., C.S.T., and C.M.L.; formal analysis, O.S., O.-R.O., I.B., C.S.T., and C.M.L.; investigation, O.S., O.-R.O., I.B., C.S.T., and C.M.L.; resources, O.S., O.-R.O., I.B., C.S.T., and C.M.L.; data curation, O.S., O.-R.O., I.B., C.S.T., and C.M.L.; writing-original draft preparation, O.S., O.-R.O., I.B., C.S.T., and C.M.L.; writing-review and editing, O.S., O.-R.O., I.B., C.S.T., and C.M.L.; visualization, O.S., O.-R.O., I.B., C.S.T., and C.M.L.; supervision, O.S., O.-R.O., I.B., C.S.T., and C.M.L.; project administration, O.S., O.-R.O., I.B., C.S.T., and C.M.L.; funding acquisition, O.S., O.-R.O., I.B., C.S.T., and C.M.L. All authors have read and agreed to the published version of the manuscript.

Funding: This research received no external funding.

Acknowledgments: The authors would like to thank the anonymous reviewers for their valuable comments and suggestions to improve the quality of the paper.

Conflicts of Interest: The authors declare no conflicts of interest.

\section{References}

1. Dermine, J. European Banking Integration: Don't Put the Cart before the Horse. Financial Mark. Inst. Instrum. 2006, 15, 57-106. [CrossRef]

2. Badîrcea, R.; Manta, A.; Pîrvu, R.; Florea, N. Banking integration in European context. Amfiteatru Econ. 2016, 18, 317-334.

3. Ferreira, C. The banking sector, economic growth and European integration. J. Econ. Stud. 2008, 35, 512-527. [CrossRef]

4. Stoica, O.; Căpraru, B. European monetary integration-Challenges for the Romanian banking system. Banks Bank Syst. 2008, 3, 14-20. 
5. Andries, A.M.; Mehdian, S.; Stoica, O. Impact of European Integration on Efficiency and Productivity Growth of Romanian Banks. Eng. Econ. 2013, 24, 187-197. [CrossRef]

6. Gropp, R.; Kashyap, A.K. A New Metric for Banking Integration in Europe. NBER 2008, 1, 1-33.

7. Thibeault, A.; Matthys, T. The Future of the Belgian Banking Industry: The Executives' Point of View; KPMG \& Vlerick Centre for Financial Services: Gent, Belgium, 2013.

8. International Monetary Fund. Financial System Stability Assessment; IMF Publication Services: Washington, DC, USA, 2012; No. 12; p. 341.

9. Maudos, J.; Vives, X. Banking in Spain. In The Palgrave Handbook of European Banking; Beck, T., Casu, B., Eds.; Palgrave Macmillan: London, UK, 2016. [CrossRef]

10. Aziakpono, M.J.; Kleimeier, S.; Sander, H. Banking market integration in the SADC countries: Evidence from interest rate analyses. Appl. Econ. 2012, 44, 3857-3876. [CrossRef]

11. Jagric Markovic-Hribernik, T. The integration of the European financial sector-The case of the banking sector. Banks Bank Syst. 2009, 4, 76-83.

12. Liang, H.-Y.; Reichert, A.K. The integration of banking and commerce: A global perspective. Banks Bank Syst. 2010, 5, 5-14.

13. Cruz-García, P.; De Guevara, J.F.; Maudos, J. The evolution of market power in European banking. Finance Res. Lett. 2017, 23, 257-262. [CrossRef]

14. Perez, D.; Salas-Fumas, V.; Saurina, J. Banking integration in Europe. In Documentos de Trabajo; Banco de Espana: Madrid, Spain, 2005; No. 0519; pp. 9-41. ISSN 0213-2710.

15. Landier, A.; Sraer, D.; Thesmar, D. Banking integration andhouse price comovement. J. Financ. Econ. 2017, 125, 1-25. [CrossRef]

16. Milcheva, S.; Zhu, B. Bank integration and co-movements across housing markets. J. Bank. Financ. 2016, 72, S148-S171. [CrossRef]

17. Beck, T.; Levine, R.; Loayza, N. Finance and the sources of growth. J. Financ. Econ. 2000, 58, 261-300. [CrossRef]

18. Bencivenga, V.R.; Smith, B.D. Financial Intermediation and Endogenous Growth. Rev. Econ. Stud. 1991, 58, 195. [CrossRef]

19. Levine, R. Financial Development and Economic Growth: Views and Agenda. J. Econ. Lit. 1997, 35, 688-726.

20. Maudos, J.; De Guevara, J.F. The economic impact of European financial integration: The importance of the banking union. Span. Rev. Financ. Econ. 2015, 13, 11-19. [CrossRef]

21. Gallizo, J.L.; Moreno, J.; Salvador, M. European Banking Integration: Is Foreign Ownership Affecting Banking Efficiency? J. Bus. Econ. Manag. 2014, 16, 340-368. [CrossRef]

22. Stavarek, D. Banking Efficiency in the Context of European Integration. East. Eur. Econ. 2006, 44, 5-31. [CrossRef]

23. Gudmundsson, M. Global Financial Integration and Central Bank Policies in Small Open Economies. Singap. Econ. Rev. 2017, 62, 135-146. [CrossRef]

24. Morgan, N.; Rime, B.; Strahan, P.E. Bank Integration and State Business Cycles. Q. J. Econ. 2004, 1555-1584. [CrossRef]

25. Păun, C.V.; Mușețescu, R.C.; Topan, V.M.; Dănulețiu, D.C. The Impact of Financial Sector Development and Sophistication on Sustainable Economic Growth. Sustainability 2019, 11, 1713. [CrossRef]

26. Vodová, P. Price indicators as a measure of Credit Market Integration in the Visegrad Countries. J. Econ. Forecast. 2011, 0, 62-73.

27. Park, Y.S. Characters and Measurement Indicators of International Financial Integration in Developing Countries; George Washington University: Washington, DC, USA, 1999.

28. Bilchak, V. Theoretical Aspects of Cross-border Integration-based Economic Cooperation. Balt. Reg. 2014, 3, 68-77. [CrossRef]

29. Vacher, J.; Saab, S.Y. Banking Sector Integration and Competition in CEMAC. IMF Work. Pap. 2007, 7, 1. [CrossRef]

30. Ak, M.Z.; Altintaş, N.; Akpolat, A.G. Does Net Interest Margin Affect Economic Growth? A Panel Data Approach. Int. Res. J. Finance Econ. 2013, 109, 137-146.

31. Arribas-Fernández, I.; Tortosa-Ausina, E. (Eds.) Banking Integration and Financial Crisis. Some Recent Developments; Fundacion BBVA: Bilbao, Spain, 2015; ISBN 978-84-92937-60-8. 
32. Arribas-Fernández, I.; Perez-Garcia, F.; Tortosa-Ausina, E. Openness and Geographic Neutrality How Do They Contribute to International Banking Integration? In Documentos de Trabajo (Working Papers 201060, BBVA Foundation); Fundacion BBVA: Bilbao, Spain, 2009; pp. 1-49.

33. Moisescu (Duican), E.R. Analysis of the Relationship Between Sustainable Development and Economic Growth. Int. Conf. Mark. Bus. Dev. 2015, 1, 138-143.

34. Barro, R.J.; Sala-i-Marin, X. Economic Growth, 2nd ed.; Massachusetts Institute of Technology: Cambridge, MA, USA, 2004.

35. Simpson, J.L. Financial Integration in European Banking Markets. Banks Bank Syst. 2006, 1, 58-74.

36. Fernando, M.; Samita, S.; Abeynayake, R. Modified Factor Analysis to Construct Composite Indices: Illustration on Urbanization Index. Trop. Agric. Res. 2012, 23, 327. [CrossRef]

37. Wang, X.; Kammerer, C.M.; Anderson, S.; Lu, J.; Feingold, E.A. Comparison of Principle Component Analysis and Factor Analysis Strategies for Uncovering Pleiotropic Factors. Genet. Epidemiol. 2009, 33, 325-331. [CrossRef]

38. OECD. Methodology and User Guide. Handbook on Constructing Composite Indicators; OECD Publications: Paris, France, 2008; No. 56327; pp. 19-2132. ISBN 978-92-64-04345-9.

39. Demertzis, M.; Sapir, A.; Wolff, G. Promoting sustainable and inclusive growth and convergence in the European Union. Policy Contrib. 2019, 7, 1-21.

40. Petkovski, M.; Kjosevski, J. Does banking sector development promote economic growth? An empirical analysis for selected countries in Central and South Eastern Europe. Econ. Res. Ekonomska Istraživanja 2014, 27, 55-66. [CrossRef]

41. Han, H.; Kil Cha, S. IMF-Association for Computing Machinery; ACM: New York, NY, USA, 2017; pp. $2345-2358$.

42. UNCTAD. The Role of Developments Banks in Promoting Growth and Sustainable Development in the South. Economic Cooperation and Integration among Developing Countries; United Nations: New York, NY, USA, 2016.

43. Lakštutienè, A. Correlation of the Indicators of the Financial system and Gross Domestic Product in European Union Countries. Eng. Econ. 2008, 58,7-18.

44. Emter, L.; Schmitz, M.; Tirpak, M. Cross-Border Banking in the EU Since the Crisis: What Is Driving the Great Retrenchment? ECB Working Paper Series; European Central Bank: Frankfurt am Main, Germany, 2018; No. 2130.

45. Verstiak, A.; Verstiak, O.; Pityk, O. Economic Convergence and The Global Crisis of 2008-2012: The Case Of Baltic Countries And Ukraine. Intellect. Econ. 2014, 8, 135-146. [CrossRef]

46. Choudry, T.; Jayasekera, R.; Kling, G. The Global Financial Crisis and the European Single Market: The end of integration? J. Int. Money Financ. 2014, 49, 191-196. [CrossRef]

47. Turk, M. Implications of European Disintegration for International Law. Columbia J. Eur. Law 2010, 17, 1-51.

48. Zielonka, J. Disintegration theory. International Implications of Europe's Crisis. Georget. J. Int. Aff. 2012, 13, 51-59.

49. Oprea, O.R. Financial Integration or Disintegration during the Financial Crisis. Rom. Econ. J. 2017, 26, $122-136$.

50. Darvas, Z.; Hüttl, P.; Merler, S.; Walsh, T. Analysis of Developments in EU Capital Flows in the Global Context.; Final Study Working Paper No. 2015.2574; European Union Bruegel: Brussels, Belgium, 2015. [CrossRef]

51. Del Hoyo, J.L.D.; Dorrucci, E.; Heinz, F.F.; Muzikarova, S. Real Convergence in the Euro Area: A Long-Term Perspective; European Central Bank: Frankfurt am Main, Germany, 2017.

52. Halmai, P.; Vásáry, V. Real convergence in the new Member States of the European Union (Shorter and longer-term prospects). Eur. J. Comp. Econ. 2010, 7, 229-253.

53. European Central Bank. Banking Structures in the New EU Member States; European Central Bank: Frankfurt am Main, Germany, 2005; pp. 5-30.

(C) 2020 by the authors. Licensee MDPI, Basel, Switzerland. This article is an open access article distributed under the terms and conditions of the Creative Commons Attribution (CC BY) license (http://creativecommons.org/licenses/by/4.0/). 